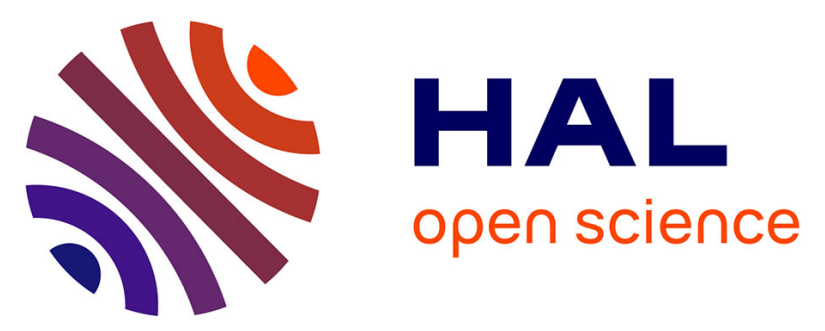

\title{
Design of Effective Catalysts Based on ZnLaZrSi Oxide Systems for Obtaining 1,3-Butadiene from Aqueous Ethanol
}

Olga V Larina, Nataliya D Shcherban, Pavlo Kyriienko, Ivan M Remezovskyi, Pavlo S Yaremov, Ivan Khalakhan, Gregor Mali, Sergiy Soloviev, Svitlana Orlyk, Stanislaw Dzwigaj

\section{To cite this version:}

Olga V Larina, Nataliya D Shcherban, Pavlo Kyriienko, Ivan M Remezovskyi, Pavlo S Yaremov, et al.. Design of Effective Catalysts Based on ZnLaZrSi Oxide Systems for Obtaining 1,3-Butadiene from Aqueous Ethanol. ACS Sustainable Chemistry \& Engineering, 2020, 8 (44), pp.16600-16611. 10.1021/acssuschemeng.0c05925 . hal-03146639

\section{HAL Id: hal-03146639 \\ https://hal.sorbonne-universite.fr/hal-03146639}

Submitted on 19 Feb 2021

HAL is a multi-disciplinary open access archive for the deposit and dissemination of scientific research documents, whether they are published or not. The documents may come from teaching and research institutions in France or abroad, or from public or private research centers.
L'archive ouverte pluridisciplinaire HAL, est destinée au dépôt et à la diffusion de documents scientifiques de niveau recherche, publiés ou non, émanant des établissements d'enseignement et de recherche français ou étrangers, des laboratoires publics ou privés. 


\section{Design of effective catalysts based on $\mathrm{ZnLaZrSi}$}

\section{oxide systems for obtaining 1,3-butadiene from}

\section{aqueous ethanol}

Olga V. Larina,,$^{\dagger}$ Nataliya D. Shcherban, ${ }^{\dagger}$ Pavlo I. Kyriienko, ${ }^{* \dagger}$ Ivan M. Remezovskyi,

Pavlo S. Yaremov, ${ }^{\dagger}$ Ivan Khalakhan, ${ }^{*}$ Gregor Mali, ${ }^{\S}$ Sergiy O. Soloviev, ${ }^{\dagger}$ Svitlana M. Orlyk, ${ }^{\dagger}$

Stanislaw Dzwigaj, */.

${ }^{\dagger}$ L.V. Pisarzhevsky Institute of Physical Chemistry of the National Academy of Sciences of Ukraine 31 Prosp. Nauky, 03028 Kyiv, Ukraine.

$\$$ Department of Surface and Plasma Science, Faculty of Mathematics and Physics, Charles

University, V Holešovičkách 2, 18000 Prague, Czech Republic.

$\S^{\S}$ Department of Inorganic Chemistry and Technology, National Institute of Chemistry,

Hajdrihova 19, SI-1001 Ljubljana, Slovenia.

" Laboratoire de Réactivité de Surface, Sorbonne Université-CNRS, UMR 7197, F-75005, Paris, France.

* E-mails: pavlo_kyriienko@ukr.net, stanislaw.dzwigaj@sorbonne-universite.fr.

KEYWORDS ethanol-water mixture, 1,3-butadiene, ZnLaZrSi oxide system, silica support. 


\section{ABSTRACT}

ZnLaZrSi oxide systems prepared with a silica component of the different nature have been studied in 1,3-butadiene production from aqueous ethanol. The following silica materials were used: KSKG, A-175, A-380, SBA-15, MCM-41, MCM-48, MCF and dealuminated BEA zeolites. The characteristics of the porous structure of the silica support, such as porosity, pore size distribution, specific and external surface areas, were found not to be critical parameters for achieving a high 1,3-butadiene yield during the EtOH- $\mathrm{H}_{2} \mathrm{O}$ mixture conversion in the presence of $\mathrm{ZnLaZrSi}$ oxide catalysts. On the contrary, the quantity and strength of Lewis acid sites, which in turn differ depending on the choice of silica material, have a significant impact on 1,3-butadiene selectivity and yield. The highest values of the selectivity of 1,3-butadiene formation (up to $68 \%$ ) and yield as well as stability toward deactivation in the presence of $\mathrm{H}_{2} \mathrm{O}$ were achieved over $\mathrm{ZnLaZr-KSKG,} \mathrm{ZnLaZr-SBA-15}$ and $\mathrm{ZnLa}-\mathrm{Zr}_{1} \mathrm{SiBEA}$ (with mononuclear isolated tetrahedral $\mathrm{Zr}(\mathrm{IV})$ species). The productivity of $\mathrm{ZnLa}-\mathrm{Zr}_{1} \mathrm{SiBEA}$ catalyst accounts for $0.324 \mathrm{~g}_{1,3-}$ $\mathrm{BD} \cdot \mathrm{g}_{\mathrm{cat}}{ }^{-1} \cdot \mathrm{h}^{-1}\left(\mathrm{~T}=648 \mathrm{~K}, \mathrm{WHSV}=2.88 \mathrm{~h}^{-1}, 80 \mathrm{vol} \% \mathrm{EtOH}\right.$ in water as an EtOH source $)$. The main reason for the decrease in 1,3-butadiene yield in the presence of $\mathrm{H}_{2} \mathrm{O}$ in the reaction mixture was shown to be a deactivation of acetaldehyde condensation sites on the catalyst surface, while the rate of acetaldehyde formation decreases slightly. According to ${ }^{1} \mathrm{H}-{ }^{13} \mathrm{C}$ CP/MAS NMR spectroscopic results, the use of aqueous ethanol as the feed for ETB-process is very advantage to prevent the carburization of the catalysts. 


\section{INTRODUCTION}

Large investments in the development of ethanol production technology from renewable raw materials contribute to a significant reduction in the costs for manufacture, and accordingly make it quite feasible to partially replace industrially important processes based on petroleum with eco-friendlier processes based on bioethanol in the near future. ${ }^{1-3}$ A number of publications ${ }^{4-6}$ are also provided justification (primarily from an environmental point of view) the starting the production of such an industrially important substrate as 1,3-butadiene (1,3-BD) from ethanol $(\mathrm{EtOH})$. In particular, the project for bio-butadiene production has been initiated in $2013 .^{7}$ Development of active and highly selective catalysts of the ethanol-to-butadiene (ETB) technology is one of the main tasks for the process implementation in industry. ${ }^{8}$

A modern approach to the process implementation of both 1,3-BD and ethylene production from ethanol involves the use of cheaper ethanol-water mixtures as raw materials that can be obtained by flash separation of fermentation ethanol, instead of expensive rectified or $100 \mathrm{vol} \%$ ethanol. For instance, the 50 vol\% ethanol can be obtained by pervaporation of fermentation broth through a membrane. Micheline company has patented the technology of the 1,3-BD production from 80 vol\% ethanol. ${ }^{9}$ Moreover, the presence of over 5-10 \% water in the feed has been shown to significantly affect activity and selectivity of the ETB process catalysts. ${ }^{15-19}$ Thus, development of the catalysts able to convert ethanol-aqueous mixtures containing 50-80 vol\% ethanol into $1,3-\mathrm{BD}$ is a very important task which is insufficiently studied now.

Based on the studies of various catalytic systems presented in the literature, activity and selectivity of catalyst in the ETB process can be concluded to equally depend on both catalyst composition and its preparation method. Most of the known catalysts contain silicon dioxide. It has been suggested that active sites of the key step of ETB process, aldol condensation, are acid- 
base pairs formed in contact of catalytically active metal cation and silicon oxide, usually depicted as M-O-Si. ${ }^{8,20}$

Effect of the used silica materials (along with catalyst composition) on activity of the ETB process catalysts is also shown in some papers. Using $\mathrm{ZrO}_{2}-\mathrm{ZnO} / \mathrm{SiO}_{2}$ and $\mathrm{ZrO}_{2}-\mathrm{ZnO}-$ $\mathrm{La}_{2} \mathrm{O}_{3} / \mathrm{SiO}_{2}$ systems, Jones et al. ${ }^{13,21}$ have shown that a pore size of $\mathrm{SiO}_{2}$ used for the catalysts preparation affects their activity in the conversion of ethanol and ethanol-acetaldehyde (EtOHAA) mixture into 1,3-BD. Sushkevich et al. ${ }^{22}$ and Dagle et al. ${ }^{23}$ have observed a relationship between butadiene selectivity and concentration of Lewis acid sites for $\mathrm{Ag} / \mathrm{ZrO}_{2}$-silica systems that depends on the nature of the used silica component. Pomalaza et al. ${ }^{24,25}$ have recently shown that ZnTa oxide catalyst based on mesoporous silica TUD-1 is more active in ETB process than similar system based on $\mathrm{SiO}_{2}$ or dealuminated BEA zeolite. Chae et al. ${ }^{26}$ have studied the effect of ordered mesoporous silica (OMS) on activity of $\mathrm{Ta}_{2} \mathrm{O}_{5} / \mathrm{OMS}$ in 1,3-BD production from EtOH-AA mixture. The pore size and particle size of OMS samples are shown to be more important than mesopore structure such as pore size and pore shape to optimize catalytic performance of $\mathrm{Ta}_{2} \mathrm{O}_{5}$-containing catalysts. Gao et al. ${ }^{27}$ have come to a similar conclusion during studying $\mathrm{ZrO}_{2}-\mathrm{SiO}_{2}$ systems prepared using various silica materials in EtOH-AA mixture conversion into 1,3-BD. Cheong et al. ${ }^{28}$ have shown that high-performance $\mathrm{ZrO}_{2}$-containing catalysts of 1,3-BD production from EtOH-AA mixture can be obtained using mesocellular siliceous foam (MCF) as a silica component. The use of zeolite as a matrix for the formation of M-O-Si active sites also allows preparing highly selective catalysts for the conversion of both EtOH and EtOH-AA mixture. ${ }^{29-35}$

In view of the foregoing considerations, the type (nature) of a silica component is assumed to have a decisive influence on activity of silica-based catalysts in 1,3-BD production from EtOH- 
$\mathrm{H}_{2} \mathrm{O}$ mixture as raw materials. As previously shown, catalytic systems containing zinc, lanthanum, zirconium and siliceous oxides exhibit quite high activity in the conversion of both ethanol and ethanol-water mixtures into 1,3-BD. ${ }^{12,36,37}$ Thus, we have used $\mathrm{ZnLaZrSi}$ oxide systems to study the effect of the silica component type on their catalytic properties in 1,3-BD production from EtOH- $\mathrm{H}_{2} \mathrm{O}$ mixture. Since there is no univocal opinion in the literature concerning the best silica support, a series of the samples based on commercially available silica (KSKG, A-175, A-380), ordered mesoporous silica (SBA-15, MCM-41, MCM-48), mesocellular siliceous foam (MCF) and dealuminated BEA zeolites was investigated.

\section{MATERIALS AND METHODS}

\section{Catalyst preparation}

KSKG industrial silica gel, aerosils A-175 and A-380, ordered mesoporous silica SBA-15, MCM-41 and MCM-48, mesocellular siliceous foam (MCF) and dealuminated BEA zeolites were used for the preparation of ZnLaZrSi oxide samples. KSKG industrial silica gel (silica gel granular with large pores, specific surface area is $283 \mathrm{~m}^{2} \mathrm{~g}^{-1}$ ) was pre-treated with dilute nitric acid, washed with double distilled water and calcined at $773 \mathrm{~K}$. Dealumination of a parent tetraethylammonium BEA zeolite $(\mathrm{Si} / \mathrm{Al}=17)$ was carried out by its treatment in a $13 \mathrm{~mol} \cdot \mathrm{L}^{-1}$ $\mathrm{HNO}_{3}$ solution at $353 \mathrm{~K}$ for $4 \mathrm{~h}$. The resulting dealuminated BEA zeolite with $\mathrm{Si} / \mathrm{Al}$ ratio of 1000 was marked as SiBEA.

Introduction of zirconium ( $6 \mathrm{wt} \%$ relative to $\mathrm{ZrO}_{2}$ ) into the silica samples (namely pre-treated KSKG, Aerosils A-175 and A-380, ordered mesoporous silica SBA-15, MCM-41, MCM-48, mesocellular siliceous foam and SiBEA) was carried out by wet kneading (fraction $<0.1 \mathrm{~mm}$ ) with analytical grade $\mathrm{ZrO}\left(\mathrm{NO}_{3}\right)_{2} \cdot 2 \mathrm{H}_{2} \mathrm{O}$, followed by drying $(393 \mathrm{~K}, 2 \mathrm{~h})$ and calcination $(773 \mathrm{~K}$, 
$3 \mathrm{~h}$ ). Introduction of zirconium into SiBEA was also carried out by stirring for $3 \mathrm{~h}$ at $353 \mathrm{~K}$ in $200 \mathrm{~mL}$ of isopropanol solution containing $1 \cdot 10^{-3} \mathrm{~mol} \cdot \mathrm{L}^{-1}$ of $\mathrm{Zr}\left(\mathrm{NO}_{3}\right)_{4} \cdot 4 \mathrm{H}_{2} \mathrm{O}$ (Sigma Aldrich, $99.9 \%$ ). The obtained suspensions $(\mathrm{pH}=6.8)$ were stirred in an evaporator under vacuum of a water pump in air at $353 \mathrm{~K}$ for $1 \mathrm{~h}$ until isopropanol was evaporated. The resulting solids, washed three times in distilled water and dried in air at $353 \mathrm{~K}$ for $24 \mathrm{~h}$, were finally calcined at $773 \mathrm{~K}$ in flowing air for $3 \mathrm{~h}$. The samples contained 1 and $3 \mathrm{wt} \%$ of $\mathrm{Zr}$ were labelled as $\mathrm{Zr}_{1} \mathrm{SiBEA}$ and $\mathrm{Zr}_{3} \mathrm{SiBEA}$.

Then, all Zr-Si oxide samples were sequentially impregnated to incipient wetness with aqueous solutions of chemically-pure-grade $\mathrm{La}\left(\mathrm{NO}_{3}\right)_{3} \cdot 6 \mathrm{H}_{2} \mathrm{O}$ and $\mathrm{Zn}\left(\mathrm{O}_{2} \mathrm{CCH}_{3}\right)_{2}$ with intermediate drying at $393 \mathrm{~K}(2 \mathrm{~h})$ and calcination at $773 \mathrm{~K}(3 \mathrm{~h})$. The $2 \mathrm{wt} \% \mathrm{ZnO}-3 \mathrm{wt} \%$ La-containing samples were prepared and marked as ZnLaZr-KSKG (A-175, A-380, SBA-15, MCM-41, MCM-48, $\mathrm{MCF}$ ) and $\mathrm{ZnLa}-\mathrm{Zr}_{1} \mathrm{SiBEA}$ and $\mathrm{ZnLa}-\mathrm{Zr}_{3} \mathrm{SiBEA}$.

\section{Catalyst characterization}

X-ray diffraction (XRD) patterns of the powder samples were recorded using a D8 Advance (Bruker AXS GmbH, Germany) diffractometer with monochromatized $\mathrm{Cu} K \alpha$ radiation (nickel filter, $\lambda=0.15418 \mathrm{~nm})$.

Nuclear magnetic resonance (NMR) spectra were recorded using a Varian VNMRS $600 \mathrm{MHz}$ spectrometer (14.1 Tesla $51 \mathrm{~mm}$ bore Oxford superconducting magnet) operating at a ${ }^{29} \mathrm{Si}$ Larmor frequency of $119.229 \mathrm{MHz}$ and using a $3.2 \mathrm{~mm}$ magic angle spinning (MAS) probe head. ${ }^{29} \mathrm{Si}$ MAS NMR spectra were recorded with cross-polarization $\left({ }^{1} \mathrm{H}^{29}{ }^{29} \mathrm{Si}\right.$ CP/MAS NMR) and without it $\left({ }^{29} \mathrm{Si}\right.$ MAS NMR). Chemical shifts of silicon were measured relative to tetramethylsilane (TMS). ${ }^{29}$ Si MAS NMR spectra were obtained with rotors spinning with a frequency of $20 \mathrm{kHz}$, 
using a single pulse acquisition and a recycle delay of $4 \mathrm{~s}$. All measurements were carried out at room temperature.

The morphology of the samples was observed by means of scanning electron microscopy (SEM) using a Tescan MIRA 3 microscope (electron beam energy of $20 \mathrm{keV}$ ).

The nitrogen adsorption-desorption isotherms were measured at $77 \mathrm{~K}$ with the porous analyzer Sorptomatic-1990. Before measurements, the samples were evacuated at $473 \mathrm{~K}$ for $2 \mathrm{~h}$. The specific surface area of the samples was determined by the Brunauer-Emmett-Teller (BET) method. External surface area and micropore volume of the investigated samples were estimated from $t$-plot method. The mesopore size of the samples were obtained by the Barrett-JoynerHalenda (BJH) method.

Analysis of acid properties of the catalyst samples was performed by adsorption of pyridine followed by Fourier Transform Infrared (FTIR) spectroscopy using a Spectrum One FTIR spectrometer (Perkin Elmer, USA). Typically, 24 scans with a resolution of $1 \mathrm{~cm}^{-1}$ were codded to give one spectrum. The catalyst sample was pressed at $\sim 2$ ton $\cdot \mathrm{cm}^{-2}$ into thin wafers of ca. $12 \mathrm{mg} \cdot \mathrm{cm}^{-2}$ and placed inside the IR cell. Before adsorption of pyridine, the cell was connected to a vacuum-adsorption apparatus allowing a residual pressure below $10^{-3} \mathrm{~Pa}$. The samples were outgassed $\left(10^{-3} \mathrm{~Pa}\right)$ at $693 \mathrm{~K}$ for $1 \mathrm{~h}$. Then, pyridine was adsorbed at $423 \mathrm{~K}$ for $15 \mathrm{~min}$. The spectra were recorded under ambient conditions after pyridine desorption at 423, 523 and $623 \mathrm{~K}$ for $30 \mathrm{~min}$. All measured spectra were recalculated to a "normalized" wafer weight and surface.

\section{Catalytic activity measurements}

Catalytic activity tests were carried out in a fixed-bed flow quartz reactor with an inner diameter of $4 \mathrm{~mm}$ at $648-673 \mathrm{~K}$ and atmospheric pressure. Samples with grains of $0.25-0.5 \mathrm{~mm}$ were loaded into the reactor. Aqueous ethanol feed (96-50 vol\% EtOH - 4-50 vol\% $\mathrm{H}_{2} \mathrm{O}$ ) was 
introduced to an evaporator via a syringe infusion pump, and argon with flow of $7 \mathrm{~mL} \cdot \min ^{-1}$ was carried the feed into the reactor. Reaction was carried out at weight hourly space velocity (WHSV) by EtOH of $0.4-1.2 \mathrm{~g}_{\text {Еон }} \cdot \mathrm{g}_{\text {cat }}{ }^{-1} \cdot \mathrm{h}^{-1}$. Before the reaction, the catalysts were annealed at $773 \mathrm{~K}$ under flowing argon for $1 \mathrm{~h}$. The reagents and reaction products were analyzed on a gas chromatograph (KristalLyuks 4000M, MetaChrome) equipped with a TCD detector and a packed column $\left(10 \% \mathrm{NiSO}_{4}\right.$ on coal, $\left.3 \mathrm{~m} \times 3 \mathrm{~mm}\right)$ for $\mathrm{CO}$ and $\mathrm{CO}_{2}$, and a FID detector and a capillary column (HP-FFAP, $50 \mathrm{~m} \times 0.32 \mathrm{~mm}$ ) for organic compounds.

Catalytic activity of the catalysts was characterized by EtOH conversion (X, \%), selectivity to products $\left(\mathrm{S}_{\mathrm{i}}, \%\right), 1,3-\mathrm{BD}$ yield $\left(\mathrm{Y}_{1,3-\mathrm{BD}}, \%\right)$ and 1,3-BD productivity $\left(\mathrm{P}_{1,3-\mathrm{BD}}, \mathrm{g}_{1,3-\mathrm{BD}} \cdot \mathrm{g}_{\mathrm{cat}}^{-1} \cdot \mathrm{h}^{-1}\right)$ :

$$
\begin{gathered}
X=\frac{n_{E t O H}^{0}-n_{E t O H}}{n_{E t O H}^{0}} \cdot 100 \%, \\
S_{i}=\frac{n_{i}}{\left(n_{E t O H}^{0}-n_{E t O H}\right)} \cdot 100 \%, \\
Y_{i}=\frac{X \cdot S_{i}}{100} \\
P_{1,3-B D}=\frac{Y_{1,3-B D} \cdot W H S V \cdot 0.587}{100},
\end{gathered}
$$

where $n^{0}{ }_{\text {EtOH }}$ is the initial amount of $\mathrm{C}_{1}$ moles of EtOH; $\mathrm{n}_{\mathrm{EtOH}}$ and $\mathrm{n}_{\mathrm{i}}$ are the amount of $\mathrm{C}_{1}$ moles of unreacted EtOH and product $i$ in the stream of the reaction products, respectively; 0.587 is the maximum possible amount of $1,3-\mathrm{BD}(\mathrm{g})$ that can be produced from $1 \mathrm{~g}$ of EtOH from a stoichiometric equation: $2 \mathrm{C}_{2} \mathrm{H}_{5} \mathrm{OH} \rightarrow \mathrm{C}_{4} \mathrm{H}_{6}+\mathrm{H}_{2}+2 \mathrm{H}_{2} \mathrm{O}$.

The formation rates of 1,3-butadiene, acetaldehyde (AA) and ethylene+diethyl ether (DEE) were calculated per unit mass of catalyst $\left(\mathrm{r}_{\mathrm{m}}, \mathrm{mmol} \cdot \mathrm{g}_{\mathrm{cat}}^{-1} \cdot \mathrm{h}^{-1}\right)$, per unit surface area $\left(\mathrm{r}_{\mathrm{s}}\right.$, $\left.\mu \mathrm{mol} \cdot \mathrm{m}^{2}{ }^{-1}{ }^{-1} \cdot \mathrm{h}^{-1}\right)$ and per unit external surface area $\left(\mathrm{r}_{\text {extern. }}, \mu \mathrm{mol} \cdot \mathrm{m}^{2}{ }_{\text {cat }}^{-1} \cdot \mathrm{h}^{-1}\right)$ :

$$
\mathrm{r}_{\mathrm{m}_{\mathrm{i}}}=\frac{\mathrm{X} \cdot \mathrm{S}_{\mathrm{i}} \cdot \mathrm{WHSV}}{\mathrm{M}_{\mathrm{EtOH}} \cdot 10}
$$




$$
\begin{gathered}
\mathrm{r}_{\mathrm{s}_{\mathrm{i}}}=\frac{1000 \cdot \mathrm{r}_{\mathrm{m}_{\mathrm{i}}}}{\mathrm{S}_{\mathrm{BET}}}, \\
\mathrm{r}_{\text {extern } \mathrm{i}}=\frac{1000 \cdot \mathrm{r}_{\mathrm{m}_{\mathrm{i}}}}{\mathrm{S}_{\text {ext. }}},
\end{gathered}
$$

where $\mathrm{M}_{\mathrm{EtOH}}$ is molar mass of ethanol $\left(\mathrm{g} \cdot \mathrm{mol}^{-1}\right)$; $\mathrm{S}_{\mathrm{BET}}$ is specific surface area of the samples determined by the Brunauer-Emmett-Teller method $\left(\mathrm{m}^{2} \cdot \mathrm{g}^{-1}\right) ; \mathrm{S}_{\mathrm{ext}}$ is external surface area of the samples $\left(\mathrm{m}^{2} \cdot \mathrm{g}^{-1}\right)$.

\section{RESULTS AND DISCUSSION}

\section{Structural and textural characteristics of the catalysts}

XRD patterns (Figure 1) of the prepared catalysts indicate amorphous structure of the supported silica materials typical of the initial silica mesoporous molecular sieves (MMS). The low-angle reflexes characteristic for the MMS supports are absent in the XRD patterns due to the filling of the support pores with the active phase resulting in an increase the number of atoms per a unit cell. The only low-intense reflection present in these XRD patterns can be attributed to monoclinic $\mathrm{ZrO}_{2}$ phase. XRD patterns of the zeolite supported samples demonstrate highly crystalline structure characteristic of BEA zeolite with main well-defined reflections at $2 \theta=7.7^{\circ}$; $22.5^{\circ}$. 


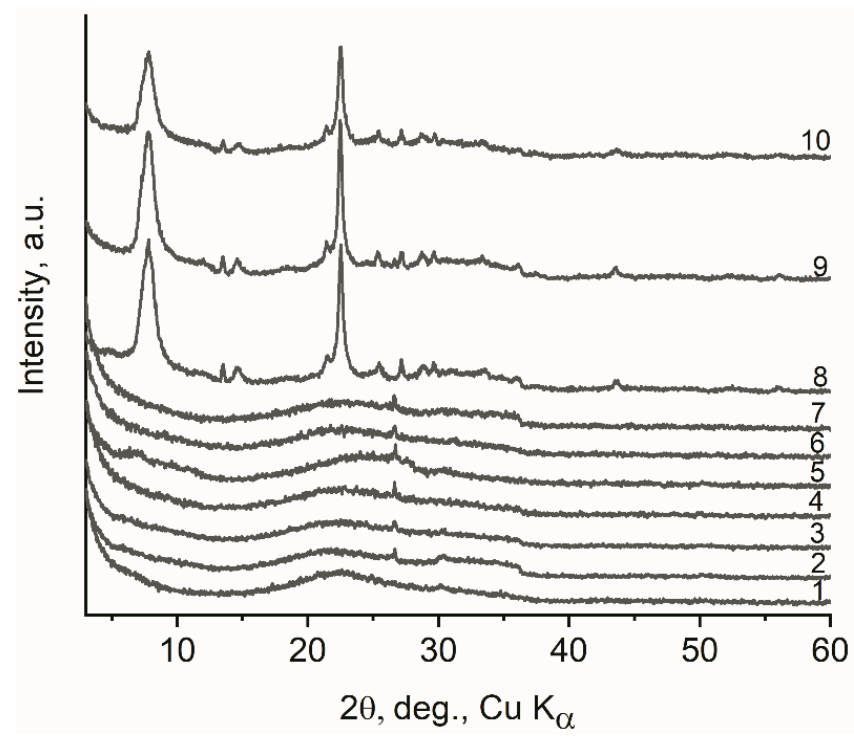

Figure 1. XRD patterns of the prepared catalysts: 1 - ZnLaZr-KSKG; 2 - ZnLaZr-A-175; 3 ZnLaZr-A-380; 4 - ZnLaZr-SBA-15; 5 - ZnLaZr-MCM-41; 6 - ZnLaZr-MCM-48; 7 ZnLaZr-MCF; 8 - ZnLaZr-SiBEA; 9 - ZnLa-Zr ${ }_{1}$ SiBEA; 10 - ZnLa-Zr ${ }_{3}$ SiBEA.

${ }^{29} \mathrm{Si}$ MAS NMR spectrum of $\mathrm{ZnLa}-\mathrm{Zr}_{3} \mathrm{SiBEA}$ zeolite presented in Figure $\mathrm{S} 1$ shows strong NMR signals in the range of -115 to $-111 \mathrm{ppm}$. These signals correspond to $\mathrm{Si}$ atoms in $\mathrm{Si}(\mathrm{OSi})_{4}$ species in non-equivalent $\mathrm{T}$ crystallographic sites (T-atoms) of BEA $(9 \text { sites })^{38}$, which are not well resolved. At about $-102 \mathrm{ppm}$ there is a weak, hardly observable ${ }^{29} \mathrm{Si}$ NMR signal of $(\mathrm{SiO})_{3} \mathrm{Si}(\mathrm{OH})$ species. Its assignment is confirmed by the ${ }^{1} \mathrm{H}^{-29} \mathrm{Si} \mathrm{CP} / \mathrm{MAS}$ NMR measurement (Figure S1 B), which significantly enhances the signal of ${ }^{29}$ Si nuclei close to protons with respect to the other ${ }^{29} \mathrm{Si}$ signals. The intensity of the peak at about $-102 \mathrm{ppm}$ for $\mathrm{ZnLa}-\mathrm{Zr}_{3} \mathrm{SiBEA}$ is very low. It confirms the presence of low amount of $(\mathrm{SiO})_{3} \mathrm{Si}(\mathrm{OH})$ species formed in the vacant $\mathrm{T}$ atom sites upon dealumination and consumed upon the reaction of these groups with incorporated zirconium cations into SiBEA zeolite, as reported earlier for $\mathrm{Nb}$ cations. ${ }^{30}$

Table 1. Structural characteristics (nitrogen ad(de)sorption, $77 \mathrm{~K}$ ) of the prepared catalysts.

Sample $\quad V_{m i}{ }^{a)}, \quad D_{m i}, \quad E_{0}, \quad V_{m e}, \quad S_{m e}{ }^{a)}, \quad D_{\text {memax }}, \quad S_{\text {ext. }}^{a)}, \quad S_{B E T}, \quad V_{\Sigma}^{c}, \quad\left|\Delta \mu_{o}\right|$,




\begin{tabular}{|c|c|c|c|c|c|c|c|c|c|c|}
\hline & $\mathrm{cm}^{3} / \mathrm{g}$ & $\mathrm{nm}$ & $\mathrm{kJ} / \mathrm{mol}$ & $\mathrm{cm}^{3} / \mathrm{g}$ & $\mathrm{m}^{2} / \mathrm{g}$ & $\mathrm{nm}$ & $\mathrm{m}^{2} / \mathrm{g}$ & $\mathrm{m}^{2} / \mathrm{g}$ & $\mathrm{cm}^{3} / \mathrm{g}$ & кJ/mol \\
\hline $\mathrm{ZnLaZr}-\mathrm{KSKG}$ & 0.02 & - & - & 0.63 & 140 & $10.1 \pm 1.9$ & 80 & 260 & 0.82 & 11.0 \\
\hline \multirow[t]{2}{*}{ ZnLaZr-A-175 } & 0.01 & - & - & - & - & $\sim 40$ & $131^{d)}$ & 160 & 0.80 & 10.5 \\
\hline & & & & & & $(5-100)$ & & & & \\
\hline ZnLaZr-A-380 & $*$ & $*$ & - & 1.05 & $170^{d)}$ & $28 \pm 9.0$ & - & 205 & 1.08 & 10.1 \\
\hline ZnLaZr-SBA-15 & 0.03 & - & - & 0.64 & 185 & $7.4 \pm 0.4$ & 80 & 340 & 0.81 & 10.9 \\
\hline ZnLaZr-MCM-41 & $*$ & $*$ & - & 0.33 & 500 & 2.2 & 40 & 615 & 0.46 & 10.8 \\
\hline ZnLaZr-MCM-48 & 0.01 & - & - & 0.50 & 255 & $6.5 \pm 0.4$ & 85 & 380 & 0.69 & 11.6 \\
\hline $\mathrm{ZnLaZr-MCF}$ & 0.01 & - & - & 0.89 & 190 & $8.8 \pm 1.5$ & 130 & 355 & 1.15 & 11.5 \\
\hline ZnLaZr-SiBEA & $0.22^{b)}$ & 0.90 & 3.9 & 0.37 & - & $\sim 50$ & 95 & 570 & 0.59 & - \\
\hline $\mathrm{ZnLa}-\mathrm{Zr}_{1} \mathrm{SiBEA}$ & $0.18^{b)}$ & 0.96 & 4.1 & - & - & $\sim 38$ & 80 & 470 & 0.37 & - \\
\hline $\mathrm{ZnLa}-\mathrm{Zr}_{3} \mathrm{SiBEA}$ & $0.14^{2)}$ & 0.96 & 4.3 & 0.17 & - & $\sim 47$ & $75^{d)}$ & 425 & 0.43 & - \\
\hline & & & & & & $(5-80)$ & & & & \\
\hline
\end{tabular}

${ }^{a}$ calculations using t-plot method, ${ }^{b}$ micropore parameters according to Dubinin-Radushkevich equation TVFM, ${ }^{c}$ total pore volume at $\mathrm{p} / \mathrm{p}_{0}=1.0,{ }^{d}$ total mesopore and external surface area, * not determined.

The particle size and morphology of ZnLaZrSi oxide samples were determined by the SEM analysis and are shown in Figure S2. The samples based on KSKG, A-175 and A-380 contain randomly amorphous particles and small sphere-like primary particles with particle diameters of around 10-20 nm. SEM image of ZnLaZr-SBA-15 shows a typical hexagonal rod-like SBA-15 morphology with a primary particle size of around $1 \mu \mathrm{m}$. ZnLaZr-MCM-41 appears as spherical particles with a regular surface. $\mathrm{ZnLaZr}-\mathrm{MCM}-48$ possesses the particles of an irregular shape. In turn, ZnLaZr-MCF consists of mainly spherical particles with a partial preservation of the cellular morphology. The images of the samples based on dealuminated BEA zeolite ( $\mathrm{ZnLa}-$ $\mathrm{Zr}_{1} \mathrm{SiBEA}$ and $\left.\mathrm{ZnLa}-\mathrm{Zr}_{3} \mathrm{SiBEA}\right)$ indicate a macrostructure similar for BEA zeolites; ${ }^{39}$ size of the 
spherical aggregates is about $100-200 \mathrm{~nm}$. Thereby, BEA zeolite does not deteriorate after treatment with nitric acid and introduction of the heteroelement $(\mathrm{Zr})$ into SiBEA.

Analysis of the nitrogen ad(de)sorption measurements (Table 1, Figure S3) shows that the prepared catalysts are characterized by the developed surface area (up to $615 \mathrm{~m}^{2} / \mathrm{g}$ ) and high total adsorption up to $\sim 1.15 \mathrm{~cm}^{3} / \mathrm{g}$ (at $\mathrm{p} / \mathrm{p}_{0}=1.0$ ). The porosity of KSKG and aerosil supported catalysts is formed as interparticle space between the aggregated silica particles. A-380 support consisting of smaller particles in comparison with A-175 provides the formation of smaller particles of the active phase. The resulting smaller particles lead to mesoporous structure with a visible bend on the isotherm in contrast to A-175 support providing larger particles of the active phase which is expressed by an adsorption increase in the region of higher relative pressures. Deposition of the active phase on silica MMS results in a decrease of the structural characteristics (specific surface area and total pore volume) of the prepared supported catalysts in comparison with the initial silica supports. The obtained materials are characterized by a comparatively homogeneous mesoporous structure indicating preferred uniform deposition of the active phase. For the samples based on SiBEA zeolite an increase in the characteristic adsorption energy in micropores $E_{0}$ is observed $(3.9,4.1,4.3 \mathrm{~kJ} / \mathrm{mol}$, Table 1; Dubinin-Radushkevich equation, TVFM) with an increase in the content of active catalytic phase, which is also confirmed by a corresponding decrease in micropore volume (Table 1). It indicates the formation of a finely dispersed phase of the catalyst components inside the micropores, and not only on the surface and their corresponding blocking.

\section{Acid characteristics of the catalysts}



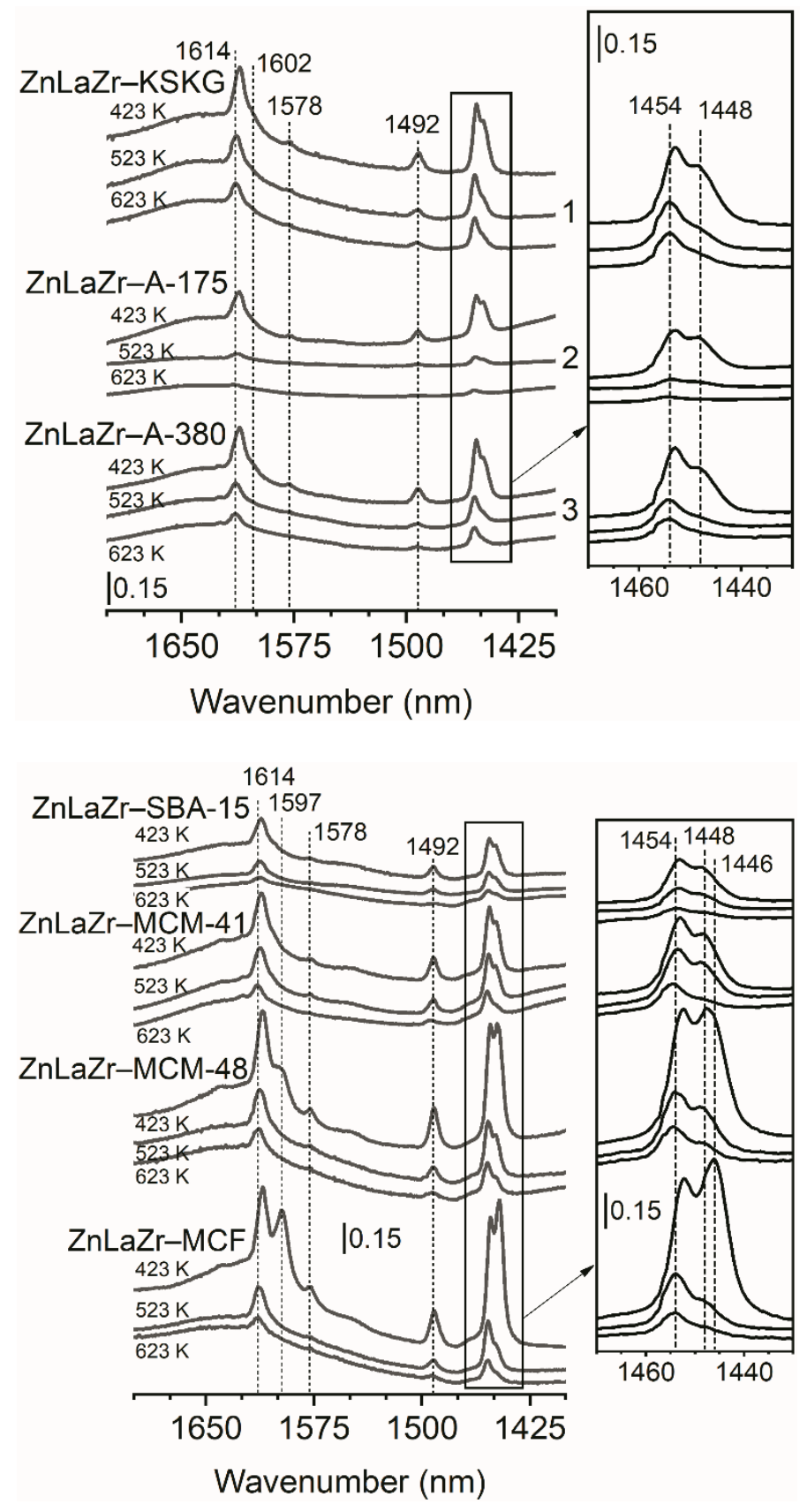


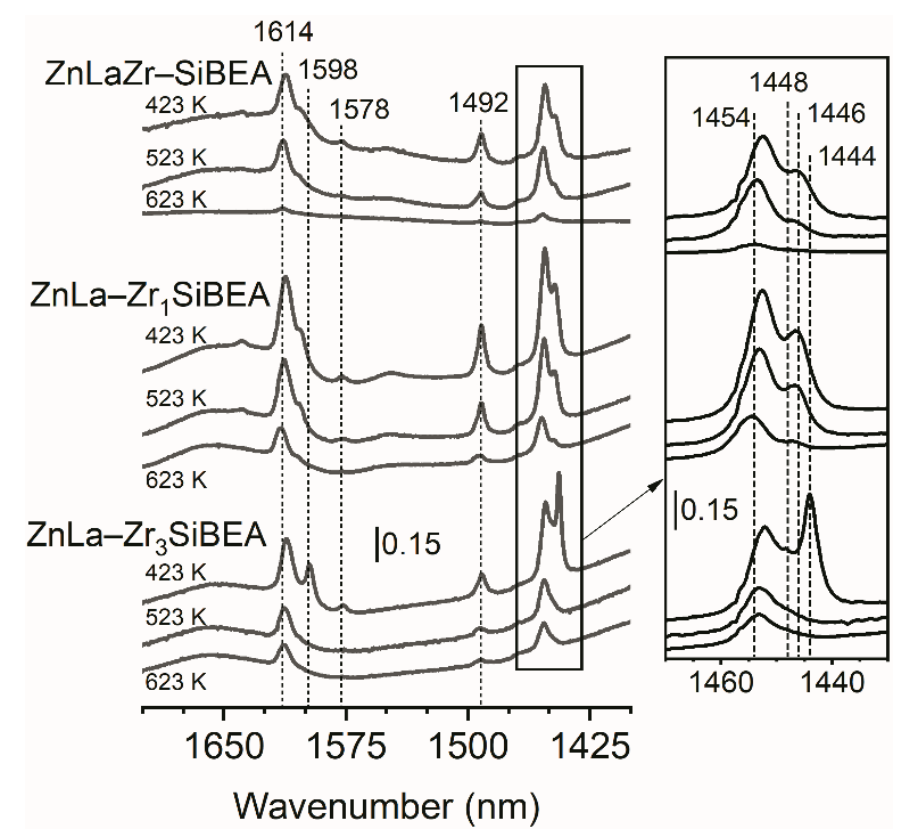

Figure 3. FTIR spectra of adsorbed pyridine the samples after their treatment at appropriate temperature.

As postulated in the Introduction section, selection of the catalyst for ETB process should be based on their acid-base properties. Figure 3 shows the results of investigation of acid sites on the catalyst surface by FTIR spectroscopy of adsorbed pyridine.

The IR adsorption bands are observed at 1614, 1602, 1578, 1492, 1454 and $1448 \mathrm{~cm}^{-1}$ for all samples. The additional bands at 1597 and $1446 \mathrm{~cm}^{-1}$ are found for ordered mesoporous silica and mesocellular siliceous foam. For dealuminated BEA zeolites one more band at $1444 \mathrm{~cm}^{-1}$ is detected. The bands at 1597,1578 and $1444 \mathrm{~cm}^{-1}$ represent physically adsorbed and hydrogenbonded pyridine, as proved by their almost complete disappearance after desorption of pyridine at $523 \mathrm{~K}$. The band at $1578 \mathrm{~cm}^{-1}$ remaining at $523 \mathrm{~K}$ arises from coordinately bonded pyridine. The band at $1492 \mathrm{~cm}^{-1}$ corresponds to both Brønsted and Lewis acid sites. ${ }^{40,41}$ However, no evidence is found for the band at $1570-1540 \mathrm{~cm}^{-1}$ on the samples indicating that there are no Brønsted sites on the surface strong enough to react with pyridine. Intensive bands at 1614,1454 
and $1448 \mathrm{~cm}^{-1}$ and the shoulder at $1602 \mathrm{~cm}^{-1}$ correspond to pyridine interacting with Lewis acid sites.

Several types of Lewis acid sites (LAS) can be formed on the surface of ZnLaZrSi oxide systems: lanthanum-, zirconium-, and zinc-containing ones. We have previously shown that only weak acid sites with a pyridine desorption temperature of up to $423 \mathrm{~K}$ are formed on the surface of LaSi oxide catalysts (the bands at 1602 and $1446 \mathrm{~cm}^{-1}$ ). ${ }^{36}$ In support of this, the poorly marked shoulder at $1602 \mathrm{~cm}^{-1}$ disappears at a pyridine desorption temperature of $523 \mathrm{~K}$. Therefore, for ZnLaZrSi oxide samples, the FTIR spectra of adsorbed pyridine after its desorption at 523 and $623 \mathrm{~K}$ contain IR adsorption bands of coordinatively bonded pyridine only with zinc- and zirconium-containing LAS. The bands at 1614 and $1454 \mathrm{~cm}^{-1}$ corresponds to $\mathrm{Zn}$ containing acid sites, as proved by the absence of these bands in the FTIR spectra of adsorbed pyridine for the samples without zinc (Figure S4). The band at 1610 and $1448 \mathrm{~cm}^{-1}$ represents Zr-containing acid sites. ${ }^{42,43}$

\section{Catalytic properties of the ZnLaZrSi-oxide systems}

Table 2. The indices of ETB process in the presence of $\mathrm{ZnLaZrSi}$ oxide systems prepared with amorphous silicon oxides $^{a}$

\begin{tabular}{|c|c|c|c|c|c|c|c|c|}
\hline \multirow[t]{2}{*}{ Catalysts } & \multirow{2}{*}{$\begin{array}{l}\text { WHSV, } \\
\mathrm{h}^{-1}\end{array}$} & \multirow{2}{*}{$\begin{array}{l}\text { EtOH } \\
\text { Conv., \% }\end{array}$} & \multicolumn{4}{|c|}{ Selectivity, $\%$} & \multirow{2}{*}{$\begin{array}{l}\text { 1,3-BD } \\
\text {-Yield, \% }\end{array}$} & \multirow{2}{*}{$\begin{array}{l}\text { 1,3-BD } \\
\text { Product., } \mathrm{g}_{1,3} \\
\mathrm{BD} \cdot \mathrm{g}_{\text {cat }}{ }^{-1} \cdot \mathrm{h}^{-1}\end{array}$} \\
\hline & & & $1,3-\mathrm{BD}$ & AA & $\begin{array}{l}\text { Ethylene } \\
+ \text { DEE }\end{array}$ & Others & & \\
\hline \multirow[t]{3}{*}{ ZnLaZr-KSKG } & 0.4 & 58.4 & 68.0 & 7.3 & 18.1 & 6.7 & 39.7 & 0.093 \\
\hline & 0.8 & 40.1 & 61.4 & 11.3 & 22.3 & 5.0 & 24.6 & 0.116 \\
\hline & 1.2 & 33.8 & 65.0 & 10.8 & 19.8 & 4.4 & 22.0 & 0.155 \\
\hline \multirow[t]{2}{*}{ ZnLaZr-A-175 } & 0.4 & 63.6 & 65.5 & 9.9 & 18.6 & 6.0 & 41.7 & 0.098 \\
\hline & 0.8 & 37.0 & 58.1 & 15.7 & 22.3 & 3.9 & 21.5 & 0.100 \\
\hline
\end{tabular}




\begin{tabular}{lcccccccc} 
& 1.2 & 26.1 & 57.4 & 16.5 & 22.9 & 3.2 & 15.0 & 0.106 \\
\hline ZnLaZr-A-380 & 0.4 & 46.1 & 60.7 & 13.7 & 21.0 & 4.6 & 28.0 & 0.066 \\
& 0.8 & 38.9 & 60.1 & 12.1 & 23.6 & 4.2 & 23.4 & 0.110 \\
& 1.2 & 28.5 & 60.0 & 12.5 & 24.2 & 3.3 & 17.1 & 0.120 \\
\hline
\end{tabular}

${ }^{a} \mathrm{~T}=648 \mathrm{~K}, \mathrm{TOS}=1-5 \mathrm{~h}, 80 \mathrm{vol} \% \mathrm{EtOH}$ in water as an EtOH source.

Table 2 presents catalytic performance of $\mathrm{ZnLaZrSi}$ oxide systems prepared with amorphous silicon oxides (KSKG, A-175, A-380) for EtOH conversion. At WHSV $=0.4 \mathrm{~h}^{-1}$, the highest values of ethanol conversion (63.6\%) and 1,3-BD yield (41.7\%) are achieved in the presence of ZnLaZr-A-175 (the sample with the lowest $S_{B E T}$ and the highest $S_{\text {ext. }}$ among the studied systems, see Table 1). With an increase in WHSV, the target process indices (ethanol conversion and 1,3BD selectivity) are decreased with a simultaneous increase in the selectivity of acetaldehyde (AA) and ethanol dehydration products (ethylene and diethyl ether, DEE). For ZnLaZr-A-175, a decrease in the target process indices is more significant than for the catalysts with a higher $S_{B E T}$ (ZnLaZr-KSKG, ZnLaZr-A-380). That may be a consequence of the fact that the concentration of Lewis acid sites on the ZnLaZr-A-175 surface is lower than for the samples based on KSKG and A-380 supports (Figure 3). At WHSV $=0.8-1.2 \mathrm{~h}^{-1}$, in the presence of ZnLaZr-KSKG and $\mathrm{ZnLaZr}-\mathrm{A}-380$ ethanol conversion is higher than for $\mathrm{ZnLaZr}-\mathrm{A}-175$. At WHSV $=1.2 \mathrm{~h}^{-1}$, the catalyst productivity of 1,3-BD formation changes in the following sequence: ZnLaZr-A-175< ZnLaZr-A-380 $<$ ZnLaZr-KSKG, which is consistent with a change in the values of $S_{B E T}$.

At similar ethanol conversion values (34-39\%), the most active catalyst is ZnLaZr-KSKG with 1,3-BD selectivity of $65 \%$ and the productivity of $0.155 \mathrm{~g}_{1,3-\mathrm{BD}} \cdot \mathrm{g}_{\mathrm{cat}}{ }^{-1} \cdot \mathrm{h}^{-1}$. The $\mathrm{ZnLaZr-KSKG}$ sample is also more selective for 1,3-BD formation at ethanol conversion values of $38.9-40.1 \%$ $\left(\right.$ at WHSV $=0.8 \mathrm{~h}^{-1}$ ). In the ref. ${ }^{23}$, higher 1,3-BD selectivity and yield are also achieved in the presence of the $1 \% \mathrm{Ag} / 4 \% \mathrm{ZrO}_{2} / \mathrm{SiO}_{2}$ catalyst based on $\mathrm{KSKG}$ support (in comparison with the 
samples based on A-380 or other types of silica). Wherein, ZnLaZr-KSKG catalyst has a maximum mesopore size of $10 \mathrm{~nm}$. In the ref. ${ }^{21}$, the $150 \mathrm{~A}^{\circ} \mathrm{ZnZrSi}$ oxide system gave a high selectivity to $1,3-\mathrm{BD}$ compared to the 40 and $60 \mathrm{~A}^{\circ}$ ones at a similar ethanol conversion too.

Among the MMS-based catalysts (Table 3), at WHSV $=0.4 \mathrm{~h}^{-1}$ the highest 1,3 -BD selectivity of $63.1 \%$ and the yield of $31.0 \%$ are achieved over ZnLaZr-SBA-15, although ethanol conversion does not exceed $49.2 \%$. In the presence of $\mathrm{ZnLaZr}-\mathrm{MCM}-48$ (a sample with porous structure characteristics comparable to the ZnLaZr-SBA-15 catalyst, Table 1), a comparable 1,3BD yield of $30.8 \%$ is achieved. Although the ethanol conversion accounts for $69.0 \%$, the selectivity of 1,3-BD formation is $44.7 \%$, which is much lower than for ZnLaZr-SBA-15. In the presence of ZnLaZr-MCM-41 and ZnLaZr-MCF (the samples with the highest $S_{B E T}$ and pore diameters/volumes, respectively, Table 1) the selectivity of 1,3-BD formation and the yield are lower than for ZnLaZr-SBA-15, also with an increase in WHSV. It should be noted that higher selectivity values towards by-products of ethanol dehydration are achieved in the presence of the catalysts based on MCM-41, MCM-48 and MCF which surface is characterized by a higher amount of weak acid sites (Figure 3, the intensity of adsorption band at $1446 \mathrm{~cm}^{-1}$ at $423 \mathrm{~K}$ ). Thus, the target process indices are less affected by the structural-dimensional characteristics of ZnLaZrSi oxide systems based on MMS than acid properties of the catalysts.

At similar ethanol conversion (47.6-52.0\%), the highest selectivity of 1,3-BD formation among the MMS-based catalysts is achieved in the presence of $\mathrm{ZnLaZr}-\mathrm{SBA}-15$. Wherein, 1,3-BD productivity of ZnLaZr-MCM-48 is the highest under such comparison conditions, but the main conversion products are ethylene and DEE. 
Table 3 The indices of ETB process in the presence of ZnLaZr-MMS mesoporous amorphous systems $^{a}$

\begin{tabular}{|c|c|c|c|c|c|c|c|c|}
\hline \multirow[t]{2}{*}{ Catalysts } & \multirow{2}{*}{$\begin{array}{l}\text { WHSV, } \\
\mathrm{h}^{-1}\end{array}$} & \multirow{2}{*}{$\begin{array}{l}\text { EtOH } \\
\text { Conv., \% }\end{array}$} & \multicolumn{4}{|c|}{ Selectivity, $\%$} & \multirow{2}{*}{$\begin{array}{l}\text { 1,3-BD } \\
\text { Yield, \% }\end{array}$} & \multirow{2}{*}{$\begin{array}{l}\text { 1,3-BD } \\
\text { Product., } \mathrm{g}_{1,3-} \\
\mathrm{BD} \cdot \mathrm{g}_{\mathrm{cat}}{ }^{-1} \cdot \mathrm{h}^{-1}\end{array}$} \\
\hline & & & $1,3-\mathrm{BD}$ & AA & $\begin{array}{l}\text { Ethylene } \\
+ \text { DEE }\end{array}$ & Others & & \\
\hline \multirow[t]{3}{*}{$\overline{Z n L a Z r-S B A-15}$} & 0.4 & 49.2 & 63.1 & 10.6 & 19.4 & 6.8 & 31.0 & 0.073 \\
\hline & 0.8 & 39.8 & 58.9 & 13.4 & 23.1 & 4.6 & 23.4 & 0.11 \\
\hline & 1.2 & 33.1 & 62.6 & 11.0 & 22.7 & 3.7 & 20.7 & 0.146 \\
\hline \multirow[t]{2}{*}{ ZnLaZr-MCM-41 } & 0.4 & 60.8 & 57.1 & 5.0 & 32.3 & 5.6 & 34.7 & 0.082 \\
\hline & 0.8 & 51.3 & 55.4 & 6.3 & 34.1 & 4.2 & 28.4 & 0.133 \\
\hline \multirow[t]{2}{*}{ ZnLaZr-MCM-48 } & 0.4 & 69.0 & 44.7 & 4.8 & 45.0 & 5.5 & 30.8 & 0.072 \\
\hline & 1.2 & 52.0 & 41.3 & 5.2 & 48.7 & 3.8 & 21.5 & 0.151 \\
\hline \multirow[t]{3}{*}{ ZnLaZr-MCF } & 0.4 & 54.5 & 48.2 & 10.4 & 36.9 & 4.3 & 26.3 & 0.062 \\
\hline & 0.8 & 47.6 & 45.4 & 9.5 & 41.1 & 4.0 & 21.6 & 0.101 \\
\hline & 1.2 & 35.0 & 44.6 & 10.7 & 42.0 & 2.7 & 15.6 & 0.110 \\
\hline
\end{tabular}

${ }^{a} \mathrm{~T}=648 \mathrm{~K}, \mathrm{TOS}=1-5 \mathrm{~h}, 80 \mathrm{vol} \% \mathrm{EtOH}$ in water as an EtOH source.

The data of catalytic performance of ZnLaZrSi oxide systems prepared with dealuminated BEA zeolite for EtOH conversion are presented in Table 4 . At WHSV $=0.4 \mathrm{~h}^{-1}$ in the presence of $\mathrm{ZnLaZr-SiBEA}$, the highest ethanol conversion of $67.4 \%$ is achieved, while $1,3-\mathrm{BD}$ selectivity is only $34.6 \%$ because of the preferred occurrence of by-product dehydration. The selectivity of ethylene and diethyl ether formation accounts for $51.3 \%$. For the catalyst samples prepared by post-synthetic method of zirconium incorporation ( $\mathrm{ZnLa}-\mathrm{Zr}_{1} \mathrm{SiBEA}, \mathrm{ZnLa}-\mathrm{Zr}_{3} \mathrm{SiBEA}$ ), the conversion of ethanol is lower (less than $58.0 \%$ ), but the selectivity of 1,3-BD formation is higher (more than $46.4 \%$ ). Such increase in 1,3-BD selectivity, despite a lower (several-fold) zirconium content in the $\mathrm{ZnLa}-\mathrm{Zr}_{1} \mathrm{SiBEA}$ catalyst sample, can be explained by the presence of 
Lewis acid sites in the framework of zeolite as isolated tetrahedral $\mathrm{Zr}(\mathrm{IV})$ species. These sites are more active in aldol condensation of acetaldehyde than zirconium present as zirconium oxide. $^{32,38}$

Table 4 The indices of ETB process in the presence of ZnLa-ZrSiBEA microporous crystalline systems $^{a}$

\begin{tabular}{|c|c|c|c|c|c|c|c|c|}
\hline \multirow[t]{2}{*}{ Catalysts } & \multirow{2}{*}{$\begin{array}{l}\text { WHSV, } \\
\mathrm{h}^{-1}\end{array}$} & \multirow{2}{*}{$\begin{array}{l}\text { EtOH } \\
\text { Conv., } \%\end{array}$} & \multicolumn{4}{|c|}{ Selectivity, \% } & \multirow{2}{*}{\multicolumn{2}{|c|}{$\begin{array}{l}\text { 1,3-BD 1,3-BD Product., } \\
\text { _Yield, \% } \mathrm{g}_{1,3-\mathrm{BD}} \cdot \mathrm{g}_{\mathrm{cat}}{ }^{-1} \cdot \mathrm{h}^{-1}\end{array}$}} \\
\hline & & & $0 \overline{1,3-\mathrm{BD}}$ & $\mathrm{AA}$ & $\begin{array}{l}\text { Ethylene } \\
+ \text { DEE }\end{array}$ & Others & & \\
\hline \multirow[t]{2}{*}{ ZnLaZr-SiBEA } & 0.4 & 67.4 & 34.6 & 7.5 & 51.3 & 6.1 & 23.3 & 0.055 \\
\hline & 1.6 & 32.8 & 30.5 & 8.8 & 53.3 & 7.4 & 12.4 & 0.070 \\
\hline \multirow[t]{2}{*}{$\mathrm{ZnLa}-\mathrm{Zr}_{1} \mathrm{SiBEA}$} & 0.4 & 58.0 & 46.4 & 12.3 & 31.6 & 9.7 & 24.1 & 0.057 \\
\hline & 2.88 & 31.1 & 61.7 & 3.4 & 12.0 & 22.9 & 19.2 & 0.324 \\
\hline \multirow[t]{3}{*}{$\mathrm{ZnLa}-\mathrm{Zr}_{3} \mathrm{SiBEA}$} & 0.4 & 36.7 & 50.8 & 19.9 & 11.8 & 17.5 & 18.6 & 0.044 \\
\hline & 0.8 & 19.9 & 51.1 & 12.5 & 10.3 & 17.1 & 10.2 & 0.048 \\
\hline & 1.2 & 14.5 & 52.0 & 21.7 & 9.9 & 16.1 & 7.5 & 0.053 \\
\hline
\end{tabular}

${ }^{a} \mathrm{~T}=648 \mathrm{~K}, \mathrm{TOS}=1-5 \mathrm{~h}, 80 \mathrm{vol} \% \mathrm{EtOH}$ in water as an EtOH source.

At similar ethanol conversion (32.8-36.7\%), the highest 1,3-BD selectivity among the microporous crystalline systems is achieved over $\mathrm{ZnLa}-\mathrm{Zr}_{1} \mathrm{SiBEA}$. The selectivity of ethylene+DEE formation is comparable for both $\mathrm{Zr}$-containing dealuminated BEA zeolites, but the residual quantity of $\mathrm{AA}$ is higher for $\mathrm{ZnLa}-\mathrm{Zr}_{3} \mathrm{SiBEA}$. In contrast, in the presence of $\mathrm{ZnLa}-$ $\mathrm{Zr}_{1} \mathrm{SiBEA}$, higher selectivity towards others products is observed, probably, because of nonselective transformation of AA. In the presence of $\mathrm{ZnLaZr-SiBEA}$, ethanol is preferably converted to ethylene and DEE.

It is worth emphasizing that ethanol conversion decreases with an increase in zirconium content in ZnLa-ZrSiBEA samples (Table 4). Such tendency may be due to an excess of 
zirconium cations in comparison with vacant $\mathrm{T}$-atom sites formed in the BEA zeolite framework upon dealumination step with nitric acid treatment and, as a result, subnanoclusters of zirconium oxide could be formed. This assumption is consistent with the results of FTIR spectroscopic measurements of adsorbed pyridine (Figure 3): at $523 \mathrm{~K}$ the intensity of the bands corresponding to Lewis acid sites is higher for $\mathrm{ZnLa}-\mathrm{Zr}_{1} \mathrm{SiBEA}$ than for $\mathrm{ZnLa}-\mathrm{Zr}_{3} \mathrm{SiBEA}$. The formation of subnanoclusters with an increase of the heteroelement content in dealuminated BEA zeolite involves a decrease in ethanol-acetaldehyde mixture conversion (without a decrease in 1,3-BD selectivity) as was previously observed for Nb-containing catalysts. ${ }^{30}$

With an increase in WHSV, a decrease in ethanol conversion is observed for both $\mathrm{ZnLa}-$ $\mathrm{ZrSiBEA}$ samples, but in the presence of $\mathrm{ZnLa}-\mathrm{Zr}_{1} \mathrm{SiBEA}$ 1,3-BD selectivity increases markedly (Figure 4). This may occur because, at a high linear flow rate, the reacting molecules primarily interact with open $\mathrm{Zr}^{4+}$ Lewis acid sites, represented by isolated $\mathrm{Zr}(\mathrm{IV})$ in tetrahedral positions of the zeolite crystalline structure and connected to three -O-Si linkages and one OH-group. According to Sushkevich et al. ${ }^{32}$, open $\mathrm{Zr}^{4+}$ Lewis acid sites are more active towards 1,3-BD formation.

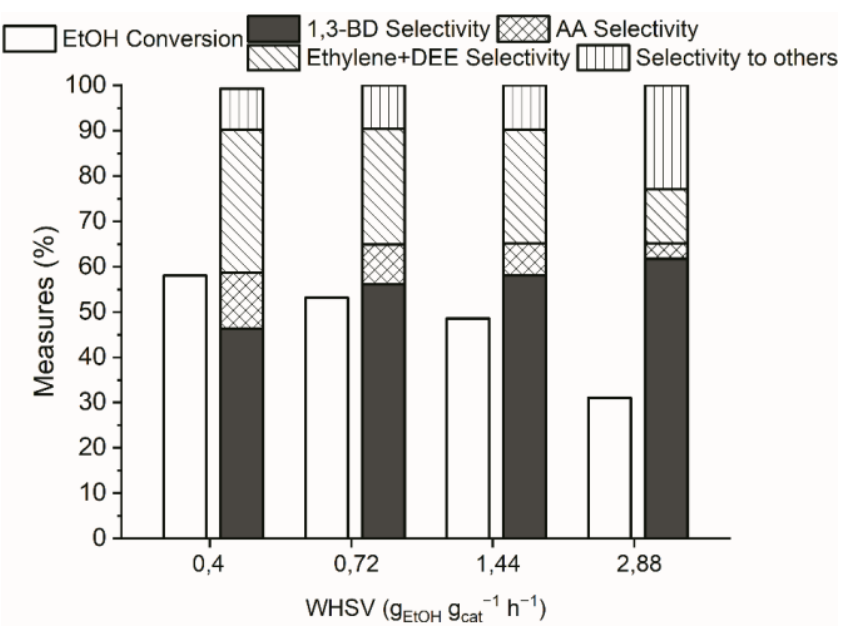


Figure 4. Effect of WHSV on ethanol conversion and selectivity to 1,3-butadiene, acetaldehyde, ethylene+diethyl ether and others products in ETB process over $\mathrm{ZnLa}-\mathrm{Zr}_{1} \mathrm{SiBEA}$ catalyst $(\mathrm{T}=$ $648 \mathrm{~K}$; time-on-stream $=1-5 \mathrm{~h} ; 80 \mathrm{vol} \% \mathrm{EtOH}$ in water as an EtOH source).

The development of catalysts containing Lewis acid sites, represented by isolated $\mathrm{Zr}^{4+}$ species, is the pathway to obtain high performance zeolite catalysts. In the presence of $\mathrm{ZnLa}-\mathrm{Zr}_{1} \mathrm{SiBEA}$, 1,3-BD formation rate reaches $1.67 \mu \mathrm{mol} \cdot \mathrm{g}_{\mathrm{cat}}{ }^{-1} \cdot \mathrm{sec}^{-1}$ during the conversion of $80 \mathrm{vol} \% \mathrm{EtOH}$ aqueous mixture at WHSV $=2.88 \mathrm{~h}^{-1}$, and accounts for $1.64,1.23$ and $0.79 \mu \mathrm{mol} \cdot \mathrm{gcat}^{-1} \cdot \mathrm{sec}^{-1}$ during the conversion of 96,80 and $50 \mathrm{vol} \% \mathrm{EtOH}$ aqueous mixtures, respectively, at WHSV $=$ $1.44 \mathrm{~h}^{-1}$. These values are comparable with those obtained in the presence of $1 \% \mathrm{Ag} / \mathrm{Zr}_{1.3} \mathrm{SiBEA}$ catalyst prepared by post-synthetic incorporation of zirconium into dealuminated BEA zeolite matrix. ${ }^{38}$ At the same time, the $\mathrm{ZnLa}-\mathrm{Zr}_{3} \mathrm{SiBEA}$ catalyst productivity of 1,3-BD formation does not reach the value for $\mathrm{ZnLa}-\mathrm{Zr}_{1} \mathrm{SiBEA}$ even with a triple increase in WHSV.

In general, among the studied $\mathrm{ZnLaZrSi}$-oxide systems, during the conversion of $80 \mathrm{vol} \%$ EtOH aqueous mixture (WHSV $=1.2 \mathrm{~h}^{-1}, \mathrm{~T}=648 \mathrm{~K}$ ) the highest catalyst productivity of 1,3-BD formation $\left(0.155 \mathrm{~g}_{1,3-\mathrm{BD}} \cdot \mathrm{g}_{\mathrm{cat}}{ }^{-1} \cdot \mathrm{h}^{-1}\right)$ is achieved for ZnLaZr-KSKG sample and a slightly lower productivity $\left(0.146 \mathrm{~g}_{1,3-\mathrm{BD}} \cdot \mathrm{g}_{\mathrm{cat}}{ }^{-1} \cdot \mathrm{h}^{-1}\right)$ for ZnLaZr-SBA-15 sample. The productivity values for $\mathrm{ZnLa}-\mathrm{Zr}_{1} \mathrm{SiBEA}$ account for $0.239 \mathrm{~g}_{1,3-\mathrm{BD}} \cdot \mathrm{g}_{\mathrm{cat}}{ }^{-1} \cdot \mathrm{h}^{-1}$ at $\mathrm{WHSV}=1.44 \mathrm{~h}^{-1}$ and $0.324 \mathrm{~g}_{1,3-\mathrm{BD}} \cdot \mathrm{g}_{\text {cat }}{ }^{-1} \cdot \mathrm{h}^{-}$ ${ }^{1}$ at WHSV $=2.88 \mathrm{~h}^{-1}$. Analyzing the data presented in Tables $2-4$, it is concluded that no significant change in the target product selectivity, i.e. in a relative change in 1,3-BD selectivity within $10 \%$ for one catalyst, with the ethanol conversion variations in the range of $20-60 \%$. This is consistent with the data obtained by Baba et al. ${ }^{44,45}$ for Zn-talk and ZnGe-talk catalysts in the mentioned ethanol conversion range. 
For $\mathrm{ZnLaZr}-\mathrm{KSKG}$ and $\mathrm{ZnLaZr}-\mathrm{SBA}-15$ catalysts, EtOH conversion has been studied as a function of time-on-stream (Figure 5). In the presence of the catalysts, the values of EtOH conversion and 1,3-BD yield do not reduce significantly with time-on-stream up to $700 \mathrm{~min}$. The constancy of 1,3-BD selectivity is also observed. A slight decrease in the selectivity to ethanol dehydration products with an increase in AA selectivity is observed after $9 \mathrm{~h}$ of operation.

The data in Figure 6 allow comparing the formation rates of 1,3-BD, acetaldehyde and ethylene+DEE, calculated per unit mass $\left(r_{m}\right)$, per unit surface area $\left(r_{s}\right)$ and per unit external surface area $\left(\mathrm{r}_{\text {extern. }}\right)$ of the catalyst. In the case of 1,3-BD formation, $\mathbf{r}_{\mathbf{m}}$ values are higher for ZnLaZr-KSKG and ZnLaZr-SBA-15 catalysts. The highest $\mathbf{r}_{\mathbf{s}}$ value of BD formation (as well as AA formation) is observed for $\mathrm{ZnLaZr}-\mathrm{A}-175$, which may be attributed to the lowest $S_{B E T}$ for

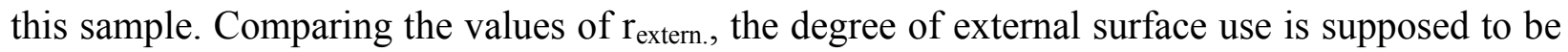
lower for ZnLaZr-A-175 as opposed to the samples based on KSKG and SBA-15. Furthermore, the $\mathrm{r}_{\text {extern. }}$ value for $\mathrm{ZnLaZr}-\mathrm{A}-175$ is comparable to that for $\mathrm{ZnLaZr}-\mathrm{MCF}$ probably because of the similar values of $S_{\text {ext }}$. Overall, the 1,3-BD formation rates are changed in the following sequences (the samples are marked as the silica support used):

$$
\begin{gathered}
\mathrm{r}_{\mathrm{m}}: \mathrm{KSKG}>\mathrm{SBA}-15>\mathrm{MCF} \geq \mathrm{A}-175>\mathrm{Zr}_{3} \mathrm{SiBEA}, \\
\mathrm{r}_{\mathrm{s}}: \mathrm{A}-175>\mathrm{KSKG}>\mathrm{SBA}-15>\mathrm{MCF}>\mathrm{Zr}_{3} \mathrm{SiBEA}, \\
\mathrm{r}_{\text {extern. }}: \mathrm{KSKG}>\mathrm{SBA}-15>\mathrm{MCF} \geq \mathrm{A}-175>\mathrm{Zr}_{3} \mathrm{SiBEA} . \\
\text { EtOH Conversion } \star \mathrm{1,3-BD} \text { Selectivity }>\text { AA Selectivity } \triangle \text { Ethylene+DEE Selectivity } \bigcirc \text { 1,3-BD Yield }
\end{gathered}
$$



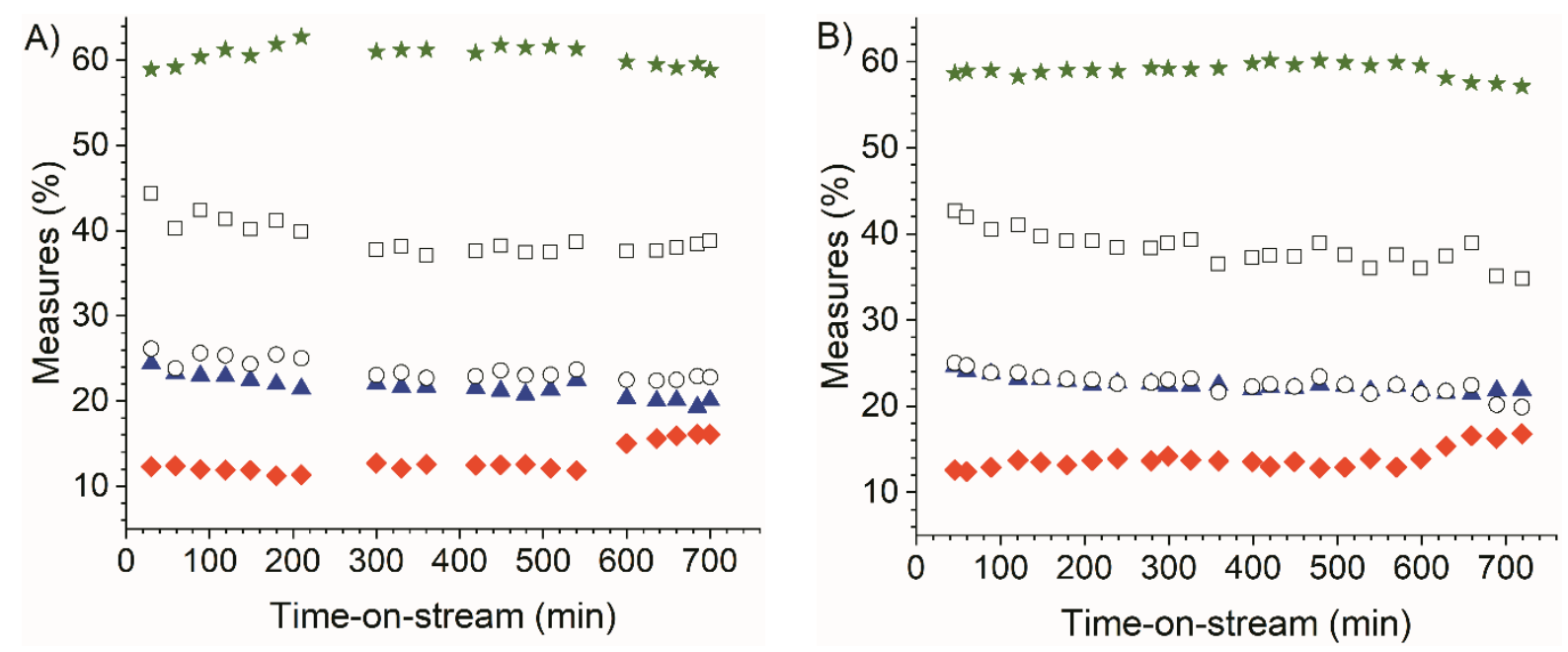

Figure 5. Ethanol conversion, 1,3-butadiene yield, and selectivity to products over $\mathrm{ZnLaZr-}$ KSKG (A) and ZnLaZr-SBA-15 (B) catalysts as a function of time-on-stream (T $=648 \mathrm{~K}$; $\mathrm{WHSV}=0.8 \mathrm{~g}_{\mathrm{EtOH}} \cdot \mathrm{g}_{\mathrm{cat}}{ }^{-1} \cdot \mathrm{h}^{-1} ; 80 \mathrm{vol} \% \mathrm{EtOH}$ in water as an EtOH source).

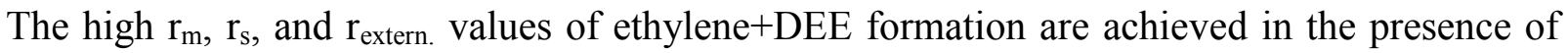
$\mathrm{ZnLaZr}-\mathrm{MCF}$, while the $\mathrm{r}_{\mathrm{s}}$ and $\mathrm{r}_{\text {extern. }}$ values are generally low for $\mathrm{ZnLa}-\mathrm{Zr}_{3} \mathrm{SiBEA}$. The lowest values of 1,3-BD formation over zeolite supported catalysts are obviously associated with the support microporosity which can be involved into the catalytic process only partially due to a limited micropore size and corresponding pore blocking. Therefore, acid characteristics of the resulting catalyst for ETB process are suggested to be more significant than high $\mathrm{S}_{\mathrm{BET}}$ and $\mathrm{S}_{\text {ext. }}$ values of the silica support used for preparation of ZnLaZrSi oxide systems. 

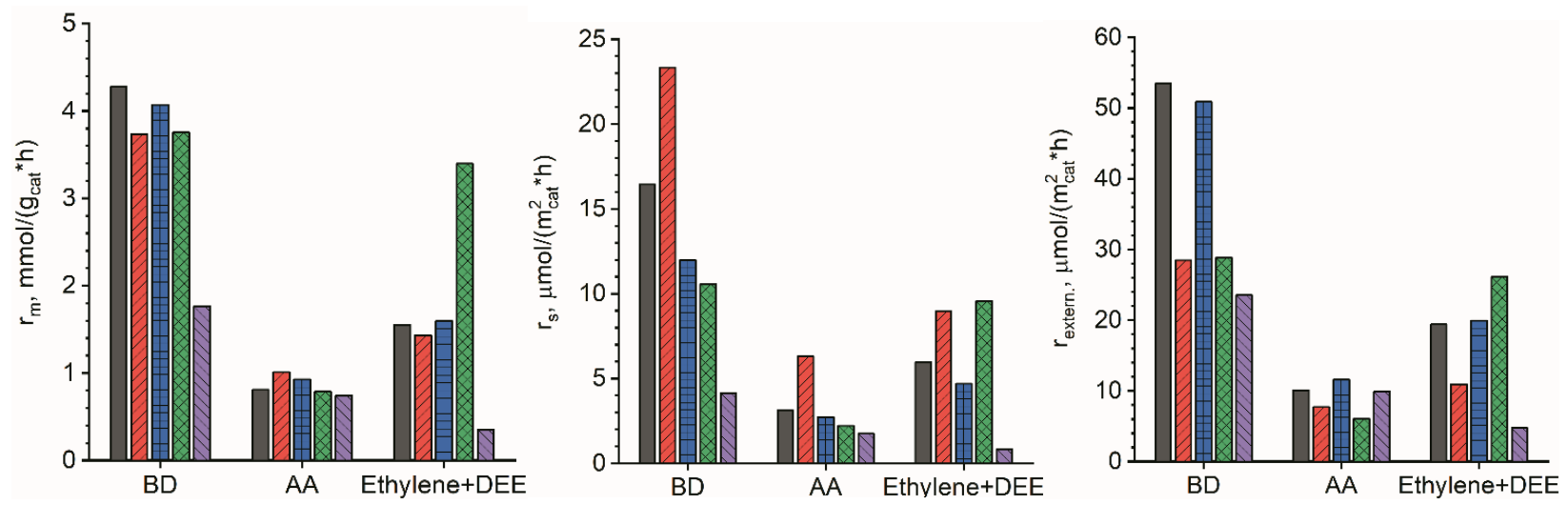

ZnLaZr-KSKG Z7ZZnLaZr-A-175

ZnLaZr-SBA-15

ZnLaZr-MCF $\triangle Z n L a-Z r_{3}$ SiBEA

Figure 6. The formation rates of 1,3-butadiene, acetaldehyde and ethylene+diethyl ether, calculated per unit mass $\left(\mathbf{r}_{\mathbf{m}}\right)$, per unit surface area $\left(\mathbf{r}_{\mathbf{s}}\right)$ and per unit external surface area $\left(\mathbf{r}_{\text {extern. }}\right)$ of the catalyst samples under the following conditions: $\mathrm{T}=648 \mathrm{~K}$; time-on-stream $=1-5 \mathrm{~h}$; $\mathrm{WHSV}=0.8 \mathrm{~g}_{\mathrm{EtOH}} \mathrm{g}_{\mathrm{cat}}{ }^{-1} \mathrm{~h}^{-1} ; .80 \mathrm{vol} \% \mathrm{EtOH}$ in water as an EtOH source.

\section{Water vapor effect on catalytic performance of the ZnLaZrSi oxide systems for ETB- process}

The water content in aqueous EtOH feed is a very important parameter affecting the target indices of ETB process. ${ }^{12,15,17,37}$ An absolute change in the values of ethanol conversion and the yields of 1,3-butadiene, acetaldehyde and ethylene+diethyl ether can be estimated using Figure 7. The complete data of catalytic performance of $\mathrm{ZnLaZrSi}$-oxide systems in EtOH-water mixture conversion are summarised in Table S1. 

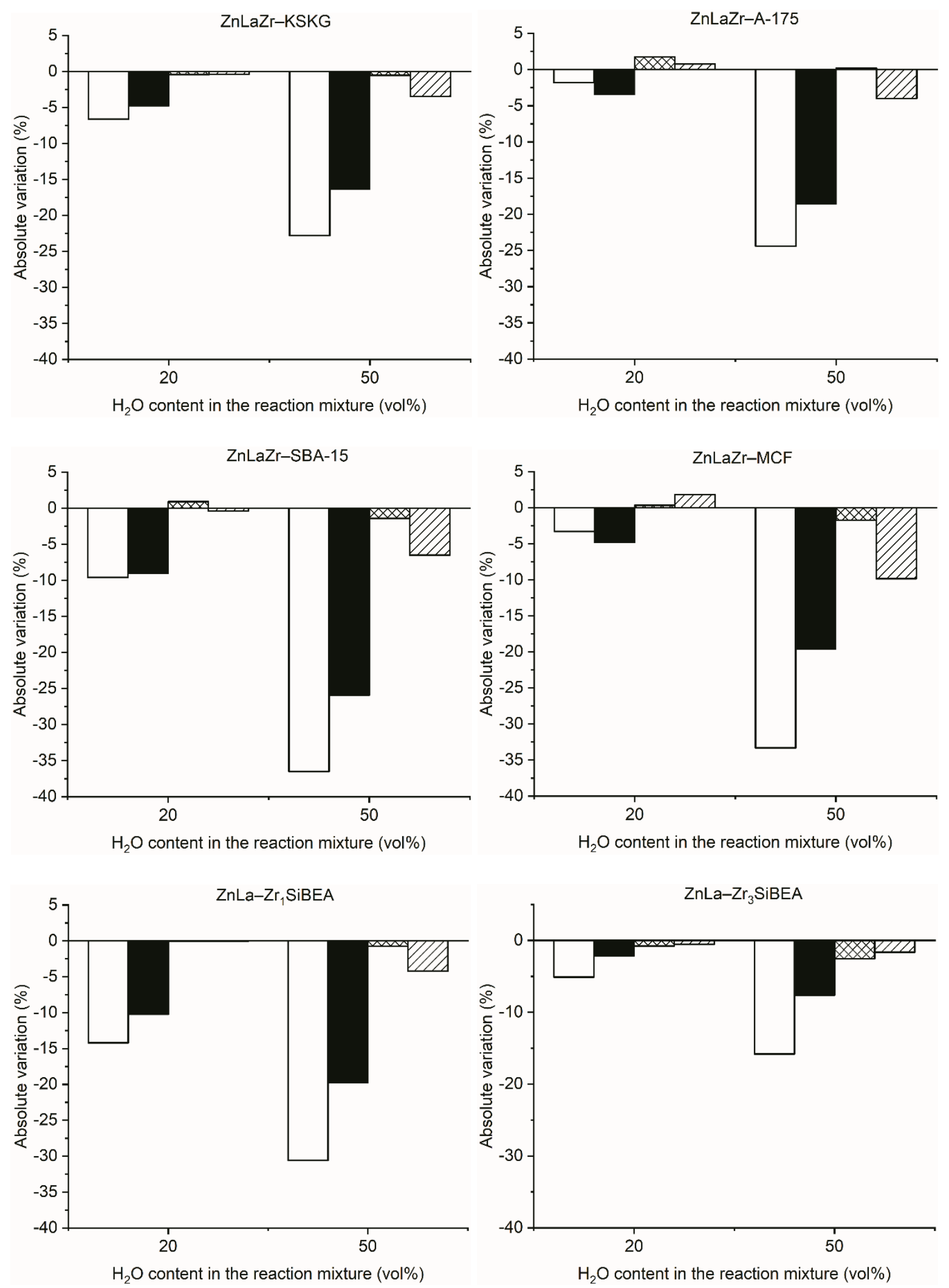

EtOH Conversion 1,3-BD Yield $\square$ AA Yield $Z \square$ Ethylene+DEE Yield 
Figure 7. Effect of water vapor on absolute change of ethanol conversion and the yields of 1,3butadiene, acetaldehyde, ethylene+diethyl ether in ETB process over ZnLaZrSi oxide systems ( $\mathrm{T}$ $=648 \mathrm{~K}$, time-on-stream $=1-5 \mathrm{~h}, \mathrm{WHSV}=0.8 \mathrm{~h}^{-1}$; for $\mathrm{ZnLa}-\mathrm{Zr}_{1} \operatorname{SiBEA}$ sample WHSV $=1.44 \mathrm{~h}^{-}$ $1)$.

With the change of $96 \mathrm{vol} \% \mathrm{EtOH}$ aqueous mixture feed to $80 \mathrm{vol} \%$ EtOH one, a noticeable decrease in both ethanol conversion and 1,3-BD selectivity is observed. 1,3-BD yield decreases by less than $5 \%$ for the catalyst samples based on $\mathrm{KSKG}, \mathrm{A}-175, \mathrm{MCF}$ and $\mathrm{Zr}_{3} \mathrm{SiBEA}$ supports, and by more than $10 \%$ for $\mathrm{ZnLaZr}-\mathrm{SBA}-15$ and $\mathrm{ZnLa}-\mathrm{Zr}_{1} \mathrm{SiBEA}$. At the same time, the selectivity to intermediate (AA) and side (ethylene+DEE) products rises to some extent. As a result, the yields of AA and ethylene+DEE are reduced by less than $2 \%$, and even rise for some catalysts. With the change of $96 \mathrm{vol} \% \mathrm{EtOH}$ aqueous mixture feed to $50 \mathrm{vol} \% \mathrm{EtOH}$ one, the values of ethanol conversion and 1,3-BD selectivity decreased more significantly. There is a substantial decrease in 1,3-BD yield. Wherein, the selectivity of ethylene+DEE formation increases by several percent, and AA selectivity almost doubles (see Table S1).

The obtained data are consistent with the results and conclusions of the ref. ${ }^{12}$ : the reason for the deactivation of ETB process catalyst is water adsorption on the LAS responsible for aldol condensation of acetaldehyde. Let's consider the effect of water vapor on activity of the catalysts to dehydrogenation (selectivity to $\mathrm{AA}$ and $1,3-\mathrm{BD}$ as the main product of $\mathrm{AA}$ aldol condensation) and dehydration (selectivity to ethylene and DEE). The selectivity of 1,3-BD formation declines however AA selectivity increases (see Table S1), and a fraction of noncondensed AA rises in the product stream. Therefore, the effect of water vapor on ethanol dehydrogenation is considered less significant than on aldol condensation. The selectivity of 
ethylene+DEE formation rises noticeably, herewith, ethylene+DEE yield is reduced along with 1,3-BD one but to varying degrees (Figure 7).

In the refs. ${ }^{15,17}$ the reason for the deactivating effect of water vapor are proposed to be $\mathrm{H}_{2} \mathrm{O}$ adsorption on LAS with their transformation to Brønsted acid sites (BAS) responsible for EtOH dehydration. However, this explanation seems to be incomplete. The water vapor released in the conversion of rectified $\mathrm{EtOH}$ into 1,3-BD and ethylene would be sufficient to hydrate the catalyst surface with the formation of low amount of BAS. Moreover, as mentioned in the ref. ${ }^{46}$, only partial blocking of LAS occurs on the hydrated surface of $\mathrm{ZrO}_{2}$. Lebedev et al. ${ }^{18}$ have noted the negative effect of the presence of water in EtOH feed on 1,3-BD yield in ETB process, whereas an increase in AA yield and a decrease in ethylene yield are observed. According to the ETB process mechanism proposed by Lebedev, C-C coupling occurs between ethylene and acetaldehyde via the Prins reaction. Therefore, the main reason for the decrease in 1,3-BD yield has been determined as a decrease in the rate of ethylene formation. Based on the thermodynamic calculations, ${ }^{3}$ in ETB process the formation of $\mathrm{C}_{4}$ products via the Prins reaction has shown to be unlikely. An increase in AA yield and a decrease in ethylene yield can be explained by a deactivation of $\mathrm{EtOH}$ dehydration sites. A decrease in the selectivity towards dehydration products with an addition of water to the feed mixture of EtOH/AA is also observed in ref. ${ }^{19,47}$ Therefore, LASs responsible for aldol condensation of acetaldehyde just remain blocked by water without forming new EtOH dehydration sites.

The $\mathrm{ZnLa}-\mathrm{Zr}_{3} \mathrm{SiBEA}$ sample is an exception in this respect. In the presence of this catalyst 1,3-BD selectivity is even higher during the conversion of $50 \mathrm{vol} \% \mathrm{EtOH}$ aqueous mixture as opposed to 96 vol\% EtOH one, while AA selectivity remains almost unchanged (Table S1). Besides, in the presence of $\mathrm{ZnLa}-\mathrm{Zr}_{1} \mathrm{SiBEA}$ an absolute decrease of 1,3-BD selectivity is less 
than for the studied non-zeolite catalysts. A similar tendency with a change in ethanol conversion, 1,3-BD and AA selectivity is also observed during the conversion of $50 \mathrm{vol} \%$ and $96 \mathrm{vol} \% \mathrm{EtOH}$ aqueous mixtures in the presence of $\mathrm{Zn}_{1} \mathrm{Ta}_{1} \mathrm{SiBEA}$ catalyst (in contrast to $\mathrm{Cu}_{1} \mathrm{Ta}_{1}$ SiBEA and $\left.\mathrm{Ag}_{1} \mathrm{Ta}_{1} \mathrm{SiBEA}\right) .{ }^{37}$ Perhaps, in the case of Zn-M-containing zeolite catalysts, the bifunctional sites like $\mathrm{Zn}-\mathrm{La}, \mathrm{Zn}-\mathrm{Zr}$, Zn-Ta species are formed in the SiBEA structure, as it has been previously noted for $\mathrm{Zn}-\mathrm{Y} /$ Beta catalysts. $^{48}$ The intermediates react with each other on these sites to generate 1,3-BD rather than desorb as unwanted byproducts. Therefore, $\mathrm{H}_{2} \mathrm{O}$ as a Lewis base is adsorbed on the catalyst surface blocking ef a part of LASs responsible for aldol condensation of acetaldehyde without the formation of new EtOH dehydration sites.

It should be noted that higher 1,3-BD selectivity is achieved during the conversion of ethanolaqueous mixtures in the presence of $\mathrm{ZnLaZr}-\mathrm{KSKG}$ as opposed to $\mathrm{ZnZr}-\mathrm{KSKG}$ (see Table S2, ${ }^{16}$ ). This may be attributed to the fact that Brønsted basic sites being active in aldol condensation $^{49-51}$ (including ETB process) ${ }^{52}$ are formed during deposition of lanthanum oxide or hydroxide on $\mathrm{SiO}_{2}{ }^{53}$ The similar lanthanum effect on EtOH conversion rates and 1,3-BD selectivity can be observed by comparing the data of the ref. ${ }^{21}$ (the conversion of $96 \mathrm{vol} \% \mathrm{EtOH}$ aqueous mixture in the presence of the $1.5 \% \mathrm{Zr}-0.5 \% \mathrm{Zn} / \mathrm{SiO}_{2}$ catalyst) and the ref. ${ }^{13}$ (the conversion of $92 \mathrm{vol} \% \mathrm{EtOH}$ aqueous mixture in the presence of the $\mathrm{ZrZn}-\mathrm{La} / \mathrm{SiO}_{2}$ catalyst). The addition of 2 wt \% lanthanum to the $\mathrm{ZrZn} / \mathrm{SiO}_{2}$ system promotes an increase in 1,3-BD selectivity, and an increase in the lanthanum content up to $3 \mathrm{wt} \%$ increases 1,3-BD yield. However, the productivity of 1,3-BD formation is higher for the unpromoted $\mathrm{ZrZn} / \mathrm{SiO}_{2}$ catalyst, as in our case.

In the lattice of dealuminated BEA zeolite, there are many unsaturated vacancies. Therefore, in the presence of $\mathrm{ZnLa}-\mathrm{ZrSiBEA}$ catalysts unvaried high 1,3-BD selectivity with the change of 
$96 \mathrm{vol} \% \mathrm{EtOH}$ aqueous mixture feed to $50-80 \mathrm{vol} \% \mathrm{EtOH}$ one (see Table S1) can be explained by a larger number of Si-O-La-OH sites formed in the dealuminated BEA zeolite.

There is another problem of slow deactivation of $\mathrm{ZnLaZrSi}$ oxide systems in ETB process at long time-on-stream, ${ }^{20}$ e.g. due to the formation of heavy by-products via condensation reactions. ${ }^{1} \mathrm{H}-{ }^{13} \mathrm{C} \mathrm{CP} / \mathrm{MAS}$ NMR investigations of organic deposits on a spent catalyst allow finding out the nature of occluded organic compounds and evaluating mechanistic aspects of deactivation. ${ }^{19,54}$

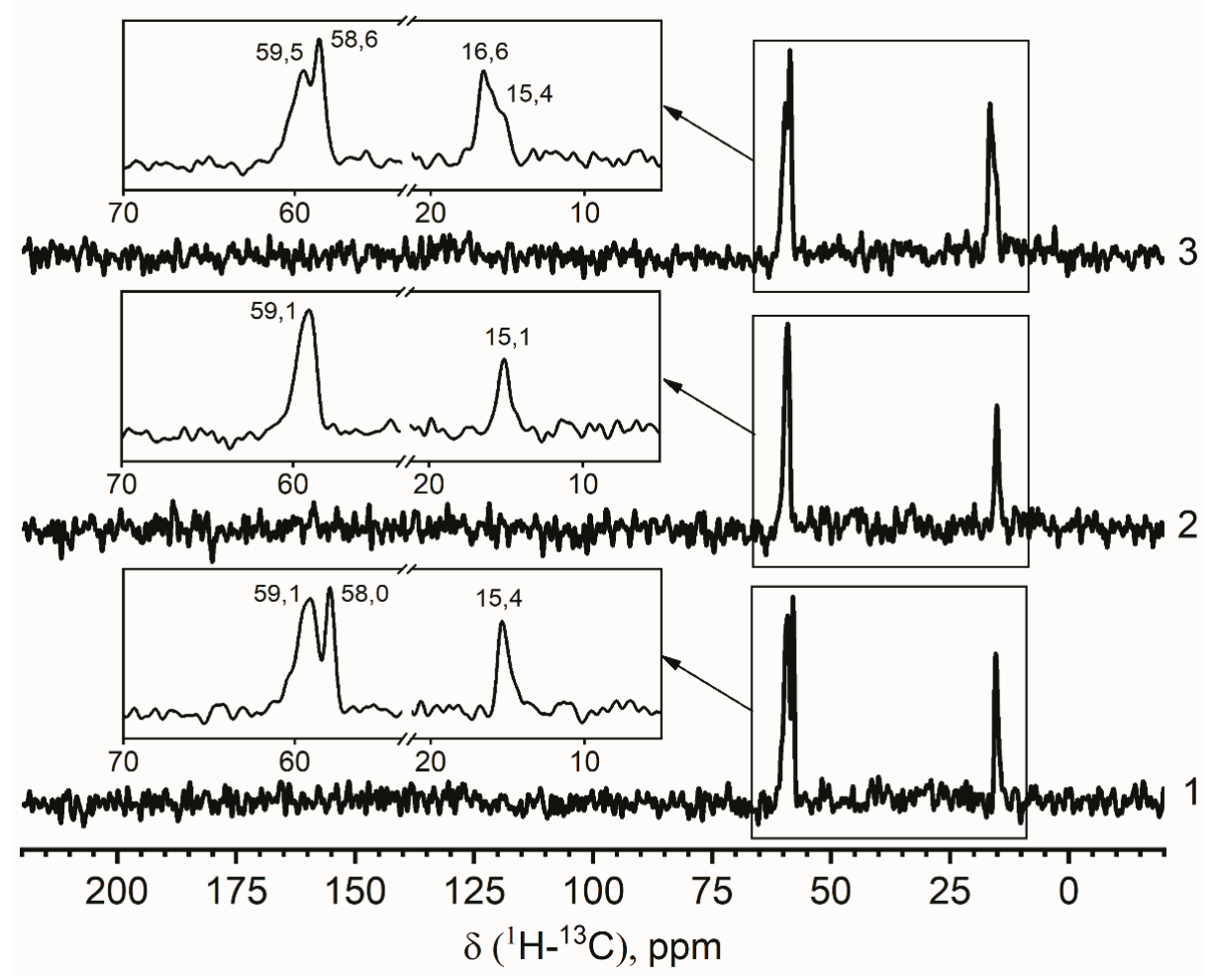

Figure 8. ${ }^{1} \mathrm{H}-{ }^{13} \mathrm{C} \mathrm{CP} / \mathrm{MAS}$ NMR spectra of the samples after catalysis: 1 - ZnLaZr-KSKG; 2 - ZnLaZr-SBA-15; 3 - ZnLa-Zr 3 SiBEA.

The ${ }^{1} \mathrm{H}-{ }^{13} \mathrm{C}$ CP/MAS NMR spectra of ZnLaZr-KSKG, ZnLaZr-SBA-15 and ZnLa-Zr 3 SiBEA catalysts obtained after operation in the ethanol to 1,3 -butadiene conversion $(\mathrm{T}=648 \mathrm{~K}$, WHSV $=$ $0.8 \mathrm{~g}_{\text {Еюн }} \mathrm{g}_{\text {cat }}{ }^{-1} \mathrm{~h}^{-1}, 80 \mathrm{vol} \% \mathrm{EtOH}$ in water as an EtOH source, time-on-stream $=5 \mathrm{~h}$ ) are shown in 
Figure 8. There are ${ }^{13} \mathrm{C}$ NMR signals at $15-17 \mathrm{ppm}$ due to primary carbon atoms in $\mathrm{CH}_{3}-\mathrm{R}$ compounds. The signals at 58-60 ppm can reflect the presence of carbon atoms in $-\mathrm{CH}_{2}-\mathrm{O}-$ and $\mathrm{CH}_{3}-\mathrm{O}$ - functional groups, and/or tertiary carbon atoms like $\mathrm{CH}(-\mathrm{R})_{3} .{ }^{55}$ The signals of alkenes, alkynes, aromatic compounds, esters, acids, aldehydes and ketones are absent, likely because these products are not formed during ETB process or are easily desorbed from the catalyst surface. Thus, the presence of water vapor in the feed prevents carburizing of the catalyst during

its operation in the ETB process, ${ }^{19}$ in particular by reducing the formation of $\mathrm{C}_{6+}$ compounds. ${ }^{17}$ In the reaction conditions water vapor, being more efficient oxidizing agent than $\mathrm{O}_{2},{ }^{56}$ can oxidize $\mathrm{C}_{6+}$ compounds at the time of their formation, when their reactivity is still high. Also, the blocking of strong acid sites being active in the formation of $\mathrm{C}_{6+}$ compounds, ${ }^{19,57}$ as a result of water vapor adsorption, helps to reduce the formation rate of these compounds. However, this topic will be the subject of a separate study.

\section{CONCLUSIONS}

The ZnLaZrSi oxide systems prepared with a silica component of the different type (nature) have been studied in the 1,3-BD production from aqueous ethanol. The commercially available silica (KSKG, A-175, A-380), ordered mesoporous silica (SBA-15, MCM-41, MCM-48), mesocellular siliceous foam (MCF) and dealuminated BEA zeolites have been used. The characteristics of the silica support porous structure, such as total porosity, pore size distribution, specific and external surface areas, are found not to be critical parameters for achieving a high 1,3-BD yield during the $\mathrm{EtOH}-\mathrm{H}_{2} \mathrm{O}$ mixture conversion in the presence of $\mathrm{ZnLaZrSi}$ oxide catalysts. The quantity and strength of Lewis acid sites, which in turn differ depending on the choice of the silica material, have a significant impact on 1,3-BD selectivity and yield. Ethylene 
and diethyl ether selectivity is increased with the concentration of weak Lewis acid sites, thereby a decrease in 1,3-butadiene selectivity is observed.

The highest values of the selectivity of 1,3-BD formation and yield as well as stability toward deactivation in the presence of water vapor are achieved over $\mathrm{ZnLa}-(6 \%) \mathrm{Zr}-\mathrm{KSKG}$, ZnLa(6 \%)Zr-SBA-15 and $\mathrm{ZnLa}-\mathrm{Zr}_{1} \mathrm{SiBEA}$ prepared by incorporation of zirconium cations in the framework of BEA zeolite as isolated tetrahedral $\mathrm{Zr}(\mathrm{IV})$ species. In the presence of $\mathrm{ZnLaZrSi}$ oxide catalysts based on MCM-41, MCM-48 and MCF with a developed porous structure, a high selectivity to ethanol dehydration products is observed, which is caused by a high amount of weak Lewis acid sites on the surface.

The main reason for the decrease in 1,3-BD yield in the presence of water vapor in the reaction mixture is shown to be the deactivation of acetaldehyde condensation sites on the catalyst surface, while the rate of acetaldehyde formation decreases slightly. In the presence of lanthanum-containing $\mathrm{ZnLaZrSi}$ oxide system the selectivity of 1,3-BD formation is enhanced. According to ${ }^{1} \mathrm{H}-{ }^{13} \mathrm{C}$ CP/MAS NMR spectroscopic results, the use of aqueous ethanol as the feed for ETB process is found to prevent carburization of the catalysts.

To prepare the $\mathrm{ZnLa}-(6 \%) \mathrm{Zr}-\mathrm{KSKG}$ catalyst, KSKG industrial silica gel (silica gel granular with large pores) has been used; it is the cheapest silica material among the used ones. Therefore, a highly efficient catalyst for ETB process can be prepared in a simple method (by wet kneading) using the mentioned inexpensive material, that will enhance the prospects for successful implementation of 1,3-butadiene production from ethanol in the future. However, the constancy of 1,3-BD selectivity is observed in the presence of the systems based on ZrSiBEA with isolated tetrahedral $\mathrm{Zr}(\mathrm{IV})$ species even using $50 \mathrm{vol} \% \mathrm{EtOH}$ aqueous mixture as a feed. Moreover, the productivity of $\mathrm{ZnLa}-\mathrm{Zr}_{1} \mathrm{SiBEA}$ catalyst accounts for $0.324 \mathrm{~g}_{1,3-\mathrm{BD}} \cdot \mathrm{g}_{\mathrm{cat}}{ }^{-1} \cdot \mathrm{h}^{-1}(\mathrm{~T}=648 \mathrm{~K}$, WHSV 
$=2.88 \mathrm{~h}^{-1}, 80 \mathrm{vol} \% \mathrm{EtOH}$ in water as an $\mathrm{EtOH}$ source). Therefore, for industrial realization of ETB process the development of the effective catalysts based on dealuminated BEA zeolites is also promising.

\section{ASSOCIATED CONTENT}

Supporting Information. The following file is available free of charge.

${ }^{29} \mathrm{Si}$ and ${ }^{1} \mathrm{H}-{ }^{29} \mathrm{Si} \mathrm{CP}$ MAS NMR spectra of $\mathrm{ZnLa}-\mathrm{Zr}_{3} \mathrm{SiBEA}$ sample, SEM images of the $\mathrm{ZnLaZrSi} \mathrm{samples} \mathrm{at} \mathrm{three} \mathrm{magnifications,} \mathrm{the} \mathrm{indices} \mathrm{of} \mathrm{EtOH-water} \mathrm{mixture} \mathrm{conversion} \mathrm{in} \mathrm{the}$ presence of $\mathrm{ZnLaZrSi}$ oxide systems, the indices of ETB process in the presence of $2 \% \mathrm{ZnO} / 6 \% \mathrm{ZrO}_{2}-\mathrm{KSKG}(\mathrm{DOCX})$.

\section{AUTHOR INFORMATION}

\section{Corresponding Authors}

* E-mails: pavlo kyriienko@ukr.net (P.K.) and stanislaw.dzwigaj@,sorbonne-universite.fr. upme.fr (S.D.).

\section{Author Contributions}

The manuscript was written through contributions of all authors. All authors have given approval to the final version of the manuscript.

\section{ACKNOWLEDGMENT}

This work was financially supported by program of National Academy of Sciences of Ukraine KPKVK 6541230 "Support for the development of priority areas of scientific research" (0120U101212), "Fundamental problems of development of new substances and materials for 
chemical industry" (0119U101562), grant of National Academy of Sciences of Ukraine for implementation of research projects of young scientists groups. P.I. Kyriienko acknowledges the CERIC-ERIC Consortium for access to experimental facilities at FESEM at the Charles University in Prague (Proposal number: 20172060) and NMR Spectrometer "Magic" at Slovenian NMR Centre (Proposal number: 20192025).

\section{REFERENCES}

(1) Abdulrazzaq, H. T.; Schwartz, T. J. Catalytic Conversion of Ethanol to Commodity and Specialty Chemicals. In Ethanol: Science and Engineering; Basile, A., Adolfo, I., Francesco, D., Nejat, V. T., Eds.; Elsevier Inc., 2019; pp 3-24. https://doi.org/10.1016/b978-0-12-811458-2.00001-8.

(2) Grim, R. G.; To, A. T.; Farberow, C. A.; Hensley, J. E.; Ruddy, D. A.; Schaidle, J. A. Growing the Bioeconomy through Catalysis: A Review of Recent Advancements in the Production of Fuels and Chemicals from Syngas-Derived Oxygenates. ACS Catal. 2019, 9, 4145-4172. https://doi.org/10.1021/acscatal.8b03945.

(3) Angelici, C.; Weckhuysen, B. M.; Bruijnincx, P. C. A. Chemocatalytic Conversion of Ethanol into Butadiene and Other Bulk Chemicals. ChemSusChem 2013, 6 (9), 15951614. https://doi.org/10.1002/cssc.201300214.

(4) Patel, A. D.; Meesters, K.; den Uil, H.; de Jong, E.; Blok, K.; Patel, M. K. Sustainability Assessment of Novel Chemical Processes at Early Stage: Application to Biobased Processes. Energy Environ. Sci. 2012, 5 (9), 8430-8444. https://doi.org/10.1039/c2ee21581k.

(5) Posada, J. A.; Patel, A. D.; Roes, A.; Blok, K.; Faaij, A. P. C.; Patel, M. K. Potential of Bioethanol as a Chemical Building Block for Biorefineries: Preliminary Sustainability Assessment of 12 Bioethanol-Based Products. Bioresour. Technol. 2013, 135, 490-499. https://doi.org/10.1016/j.biortech.2012.09.058. 
(6) Cespi, D.; Passarini, F.; Vassura, I.; Cavani, F. Butadiene from Biomass, a Life Cycle Perspective to Address Sustainability in the Chemical Industry. Green Chem. 2016, 18, 1625-1638. https://doi.org/10.1039/C5GC02148K.

(7) Axens, IFPEN and Michelin Join Forces to Create a Synthetic Rubber Production Channel Using Biomass.

(8) Pomalaza, G.; Capron, M.; Ordomsky, V.; Dumeignil, F. Recent Breakthroughs in the Conversion of Ethanol to Butadiene. Catalysts 2016, $6 \quad$ (12), 203. https://doi.org/10.3390/catal6120203.

(9) Dastillung, R.; Fischer, B.; Jacquin, M.; Huyghe, R. Method for the Production of Butadiene from Ethanol in One Low-Water- and Low-Energy-Consumption Reaction Step. US 20170267604 A1, 2017.

(10) Rossetti, I.; Compagnoni, M.; Finocchio, E.; Ramis, G.; Di Michele, A.; Millot, Y.; Dzwigaj, S. Ethylene Production via Catalytic Dehydration of Diluted Bioethanol: A Step towards an Integrated Biorefinery. Appl. Catal. B Environ. 2017, 210, 407-420. https://doi.org/10.1016/j.apcatb.2017.04.007.

(11) Rossetti, I.; Compagnoni, M.; De Guido, G.; Pellegrini, L. A.; Ramis, G.; Dzwigaj, S. Ethylene Production from Diluted Bioethanol Solutions. Can. J. Chem. Eng. 2017, 95 (9), 1752-1759. https://doi.org/10.1002/cjce.22828.

(12) Larina, O. V; Remezovskyi, I. M.; Kyriienko, P. I.; Soloviev, S. O.; Orlyk, S. M. 1,3Butadiene Production from Ethanol-Water Mixtures over Zn-La-Zr-Si Oxide Catalyst. React. Kinet. Mech. Catal. 2019, 127 (2), 903-915. https://doi.org/10.1007/s11144-01901618-5.

(13) Lewandowski, M.; Ochenduszko, A.; Jones, M. D. Process for the Production of 1,3Butadiene. Wo 2014/180778 a1. 2014.

(14) Cai, D.; Zhu, Q.; Chen, C.; Hu, S.; Qin, P.; Wang, B.; Tan, T. FermentationPervaporation-Catalysis Integration Process for Bio-Butadiene Production Using Sweet Sorghum Juice as Feedstock. J. Taiwan Inst. Chem. Eng. 2018, 82, 137-143. 
https://doi.org/10.1016/j.jtice.2017.11.002.

(15) Velasquez Ochoa, J.; Bandinelli, C.; Vozniuk, O.; Chieregato, A.; Malmusi, A.; Recchi, C.; Cavani, F. An Analysis of the Chemical, Physical and Reactivity Features of MgO$\mathrm{SiO} 2$ Catalysts for Butadiene Synthesis with the Lebedev Process. Green Chem. 2016, 18, 1653-1663. https://doi.org/10.1039/C5GC02194D.

(16) Larina, O. V.; Kyriienko, P. I.; Balakin, D. Y.; Vorokhta, M.; Khalakhan, I.; Nychiporuk, Y. M.; Matolín, V.; Solovieva, S. O.; Orlyk, S. M. The Effect of ZnO on Acid-Base Properties and Catalytic Performance of $\mathrm{ZnO} / \mathrm{ZrO} 2-\mathrm{SiO} 2$ Catalysts in 1,3-Butadiene Production from Ethanol-Water Mixture. Catal. Sci. Technol. 2019, 9, 3964-3978. https://doi.org/10.1039/C9CY00991D.

(17) Cabello González, G. M.; Concepciónb, P.; Villanueva Peralesa, A. L.; Martínezb, A.; Campoya, M.; Vidal-Barrero, F. Ethanol Conversion into 1,3-Butadiene over a Mixed HfZn Catalyst: Effect of Reaction Conditions and Water Content in Ethanol. Fuel Process. Technol. 2019, 193 (December 2018), 263-272. https://doi.org/10.1016/j.apcata.2018.11.010.

(18) Talalay, A.; Talalay, L. S. K.-The Russian Synthetic Rubber from Alcohol. A Survey of the Chemistry and Technology of the Lebedev Process for Producing Sodium-Butadiene Polymers. Rubber Chem. Technol. 1942, 15 (3), 403-429. https://doi.org/10.5254/1.3543128.

(19) Zhang, M.; Tan, X.; Zhang, T.; Hanab, Z.; Jiang, H. The Deactivation of ZnO Doped $\mathrm{ZrO} 2-\mathrm{SiO} 2$ Catalyst in the Conversion of Ethanol/Acetaldehyde to 1,3-Butadiene. RSC $A d v$. 2018, 8, 34069-34077. https://doi.org/10.1039/C8RA06757K.

(20) Makshina, E. V.; Dusselier, M.; Janssens, W.; Degrève, J.; Jacobs, P. A.; Sels, B. F. Review of Old Chemistry and New Catalytic Advances in the On-Purpose Synthesis of Butadiene. Chem. Soc. Rev. 2014, 43 (22), 7917-7953. https://doi.org/10.1039/C4CS00105B.

(21) Jones, M. D.; Keir, C. G.; Di Iulio, C.; Robertson, R. A. M.; Williams, C. V.; Apperley, D. 
C. Investigations into the Conversion of Ethanol into 1,3-Butadiene. Catal. Sci. Technol. 2011, 1 (2), 267-272. https://doi.org/10.1039/c0cy00081g.

(22) Sushkevich, V. L.; Ivanova, I. I.; Taarning, E. Ethanol Conversion into Butadiene over ZrContaining Molecular Sieves Doped with Silver. Green Chem. 2015, 17 (4), 2552-2559. https://doi.org/10.1039/C4GC02202E.

(23) Dagle, V. L.; Flake, M. D.; Lemmon, T. L.; Lopez, J. S.; Kovarik, L.; Dagle, R. A. Effect of the $\mathrm{SiO} 2$ Support on the Catalytic Performance of $\mathrm{Ag} / \mathrm{ZrO} 2 / \mathrm{SiO} 2$ Catalysts for the Single-Bed Production of Butadiene from Ethanol. Appl. Catal. B Environ. 2018, 236, 576-587. https://doi.org/10.1016/j.apcatb.2018.05.055.

(24) Pomalaza, G.; Vofo, G.; Capron, M.; Dumeignil, F. ZnTa-TUD-1 as an Easily Prepared, Highly Efficient Catalyst for the Selective Conversion of Ethanol to 1,3-Butadiene. Green Chem. 2018, 20, 3203-3209. https://doi.org/10.1039/C8GC01211C.

(25) Pomalaza, G.; Simon, P.; Addad, A.; Capron, M.; Dumeignil, F. Properties and Activity of Zn-Ta-TUD-1 in the Lebedev Process. Green Chem. 2020, 22 (8), 2558-2574. https://doi.org/10.1039/d0gc00103a.

(26) Chae, H.-J.; Kim, T.-W.; Moon, Y.-K.; Kim, H.-K.; Jeong, K.-E.; Kim, C.-U.; Jeong, S.Y. Butadiene Production from Bioethanol and Acetaldehyde over Tantalum OxideSupported Ordered Mesoporous Silica Catalysts. Appl. Catal. B Environ. 2014, 150-151, 596- 604. https://doi.org/10.1016/j.cej.2014.09.110.

(27) Gao, M.; Zhang, M.; Jiang, H. 1,3-Butadiene Production from Bioethanol and Acetaldehyde over Zirconium Oxide Supported on Series Silica Catalysts. Catal. Surv. from Asia 2018, 22, 118-122. https://doi.org/10.1007/s10563-018-9243-8.

(28) Cheong, J. L.; Shao, Y.; Tan, S. J. R.; Li, X.; Zhang, Y.; Lee, S. S. Highly Active and Selective $\mathrm{Zr} / \mathrm{MCF}$ Catalyst for Production of 1,3-Butadiene from Ethanol in a Dual Fixed Bed Reactor System. ACS Sustain. Chem. Eng. 2016, 4 (9), 4887-4894. https://doi.org/10.1021/acssuschemeng.6b01193.

(29) Kyriienko, P. I.; Larina, O. V.; Soloviev, S. O.; Orlyk, S. M.; Calers, C.; Dzwigaj, S. 
Ethanol Conversion into 1,3-Butadiene by the Lebedev Method over MTaSiBEA Zeolites $(\mathrm{M}=\mathrm{Ag}, \mathrm{Cu}, \mathrm{Zn})$. ACS Sustain. Chem. Eng. 2017, 5 (3), 2075-2083. https://doi.org/10.1021/acssuschemeng.6b01728.

(30) Kyriienko, P. I.; Larina, O. V; Popovych, N. O.; Soloviev, S. O.; Millot, Y.; Dzwigaj, S. Effect of the Niobium State on the Properties of NbSiBEA as Bifunctional Catalysts for Gas- and Liquid-Phase Tandem Processes. J. Mol. Catal. A. Chem. 2016, 424, 27-36. https://doi.org/10.1016/j.molcata.2016.06.024.

(31) Kyriienko, P. I.; Larina, O. V.; Soloviev, S. O.; Orlyk, S. M.; Dzwigaj, S. High Selectivity of TaSiBEA Zeolite Catalysts in 1,3-Butadiene Production from Ethanol and Acetaldehyde Mixture. Catal. Commun. 2016, 77, 123-126. https://doi.org/10.1016/j.catcom.2016.01.023.

(32) Sushkevich, V. L.; Palagin, D.; Ivanova, I. I. With Open Arms: Open Sites of ZrBEA Zeolite Facilitate Selective Synthesis of Butadiene from Ethanol. ACS Catal. 2015, 5 (8), 4833-4836. https://doi.org/10.1021/acscatal.5b01024.

(33) Klein, A.; Keisers, K.; Palkovits, R. Formation of 1,3-Butadiene from Ethanol in a TwoStep Process Using Modified Zeolite- $\beta$ Catalysts. Appl. Catal. A Gen. 2016, 514, $192-$ 202. https://doi.org/10.1016/j.apcata.2016.01.026.

(34) Klein, A.; Palkovits, R. Influence of Structural Parameters on the Conversion of Ethanol into 1,3-Butadiene Using Mesoporous Zeolites. Catal. Commun. 2017, 91, 72-75. https://doi.org/10.1016/j.catcom.2016.12.009.

(35) Kurmach, M. M.; Larina, O. V.; Kyriienko, P. I.; Yaremov, P. S.; Trachevsky, V. V.; Shvets, O. V.; Soloviev, S. O. Hierarchical Zr-MTW Zeolites Doped with Copper as Catalysts of Ethanol Conversion into 1,3-Butadiene. ChemistrySelect 2018, 3 (29), 85398546. https://doi.org/10.1002/slct.201801971.

(36) Larina, O. V.; Kyriienko, P. I.; Soloviev, S. O. Effect of Lanthanum in Zn-La(-Zr)-Si Oxide Compositions on Their Activity in the Conversion of Ethanol into 1,3-Butadiene. Theor. Exp. Chem. 2016, 52 (1), 51-56. https://doi.org/10.1007/s11237-016-9450-1. 
(37) Kyriienko, P. I.; Larina, O. V; Dzwigaj, S.; Soloviev, S. O.; Orlyk, S. M. Effect of the Composition of Ethanol - Water Mixtures on the Properties of Oxide ( $\mathrm{Zn}-\mathrm{Zr}-\mathrm{Si})$ and Zeolitic (Ta/SiBEA) Catalysts in the Production of 1,3-Butadiene. Theor. Exp. Chem. 2019, 55 (4), 241-247. https://doi.org/10.1007/s11237-019-09618-1.

(38) Sushkevich, V. L.; Ivanova, I. I. Ag-Promoted ZrBEA Zeolites Obtained by PostSynthetic Modification for Conversion of Ethanol to Butadiene. ChemSusChem 2016, 9 , 2216-2225. https://doi.org/10.1002/cssc.201600572.

(39) Radhakrishnan, S.; Goossens, P. J.; Magusin, P. C. M. M.; Sree, S. P.; Detavernier, C.; Breynaert, E.; Martineau, C.; Taulelle, F.; Martens, J. A. In Situ Solid-State13C NMR Observation of Pore Mouth Catalysis in Etherification of $\beta$-Citronellene with Ethanol on Zeolite Beta. J. Am. Chem. Soc. 2016, 138 (8), 2802-2808. https://doi.org/10.1021/jacs.5b13282.

(40) Yurdakoç, M.; Akçay, M.; Tonbul, Y.; Yurdakoç, K. Acidity of Silica-Alumina Catalysts by Amine Titration Using Hammett Indicators and FT-IR Study of Pyridine Adsorption. Turkish J. Chem. 1999, 23 (3), 319-327.

(41) Connell, G.; Dumesic, J. A. The Generation of Brønsted and Lewis Acid Sites on the Surface of Silica by Addition of Dopant Cations. J. Catal. 1987, 105 (2), 285-298. https://doi.org/10.1016/0021-9517(87)90059-5.

(42) Larina, O. V.; Kyriienko, P. I.; Soloviev, S. O. Effect of the Addition of Zirconium Dioxide on the Catalytic Properties of $\mathrm{ZnO} / \mathrm{MgO}-\mathrm{SiO}<\mathrm{inf}>2</ \mathrm{Inf}>$ Compositions in the Production of 1,3-Butadiene from Ethanol. Theor. Exp. Chem. 2015, 51 (4), 252-258. https://doi.org/10.1007/s11237-015-9424-8.

(43) Larina, O. V.; Kyriienko, P. I.; Soloviev, S. O. Ethanol Conversion to 1,3-Butadiene on $\mathrm{ZnO} / \mathrm{MgO}-\mathrm{SiO} 2$ Catalysts: Effect of $\mathrm{ZnO}$ Content and $\mathrm{MgO}: \mathrm{SiO} 2$ Ratio. Catal. Letters 2015, 145 (5), 1162-1168. https://doi.org/10.1007/s10562-015-1509-4.

(44) Hayashi, Y.; Akiyama, S.; Miyaji, A.; Sekiguchi, Y.; Sakamoto, Y.; Shiga, A.; Koyama, T.; Motokura, K.; Baba, T. Experimental and Computational Studies of the Roles of MgO 
and $\mathrm{Zn}$ in Talc for the Selective Formation of 1,3-Butadiene in the Conversion of Ethanol. Phys. Chem. Chem. Phys. 2016, 18, 25191-25209. https://doi.org/10.1039/C6CP04171J.

(45) Akiyama, S.; Miyaji, A.; Hayashi, Y.; Hiza, M.; Sekiguchi, Y.; Koyama, T.; Shiga, A.; Baba, T. Selective Conversion of Ethanol to 1,3-Butadiene Using Germanium Talc as Catalyst. J. Catal. 2018, 359, 184-197. https://doi.org/10.1016/j.jcat.2018.01.001.

(46) Santos, K. M. A.; Albuquerque, E. M.; Innocenti, G.; Borges, L. E. P.; Sievers, C.; Fraga, M. A. The Role of Brønsted and Water-Tolerant Lewis Acid Sites in the Cascade Aqueous-Phase Reaction of Triose to Lactic Acid. ChemCatChem 2019, 11, 3054-3063. https://doi.org/10.1002/cctc.201900519.

(47) Zhu, Q.; Wang, B.; Tan, T. Conversion of Ethanol and Acetaldehyde to Butadiene over $\mathrm{MgO}-\mathrm{SiO} 2$ Catalysts: Effect of Reaction Parameters and Interaction between $\mathrm{MgO}$ and $\mathrm{SiO} 2$ on Catalytic Performance. ACS Sustain. Chem. Eng. 2016, 5 (1), 722-733. https://doi.org/10.1021/acssuschemeng.6b02060.

(48) Yan, T.; Dai, W.; Wu, G.; Lang, S.; Hunger, M.; Guan, N.; Li, L. Mechanistic Insights into One-Step Catalytic Conversion of Ethanol to Butadiene over Bifunctional Zn-Y/Beta Zeolite. ACS Catal. 2018, 8, 2760-2773. https://doi.org/10.1021/acscatal.8b00014.

(49) Singh, A.; Palakollu, V.; Pandey, A.; Kanvah, S.; Sharma, S. Green Synthesis of 1,4Benzodiazepines over $\mathrm{La} 2 \mathrm{O} 3$ and $\mathrm{La}(\mathrm{OH}) 3$ Catalysts: Possibility of LangmuirHinshelwood Adsorption. RSC Adv. 2016, 6, 103455-103462. https://doi.org/10.1039/c6ra22719h.

(50) Lippert, S.; Baumann, W.; Thomke, K. Secondary Reactions of the Base-Catalyzed Aldol Condensation of Acetone. J. Mol. Catal. 1991, 69 (2), 199-214. https://doi.org/10.1016/0304-5102(91)80145-S.

(51) Frey, A. M.; Karmee, S. K.; de Jong, K. P.; Bitter, J. H.; Hanefeld, U. Supported La2O3 and $\mathrm{MgO}$ Nanoparticles as Solid Base Catalysts for Aldol Reactions While Suppressing Dehydration at Room Temperature. ChemCatChem 2013, 5 (2), 594-600. https://doi.org/10.1002/cctc.201200282. 
(52) Kyriienko, P. I.; Larina, O. V.; Balakin, D. Y.; Sergiienko, S. A.; Soloviev, S. O. Effect of the Composition of Silver Doped M-Si Oxide Systems (M: Mg, Zr, La) on Their Catalytic Properties in the Conversion of Ethanol to 1,3-Butadiene. Theor. Exp. Chem. 2020, 56 (1), 33-38. https://doi.org/10.1007/s11237-020-09637-3.

(53) Mekhemer, G. A. H. Surface Structure and Acid-Base Properties of Lanthanum Oxide Dispersed on Silica and Alumina Catalysts. Phys. Chem. Chem. Phys. 2002, 4 (21), 54005405. https://doi.org/10.1039/b204056p.

(54) Yan, T.; Yang, L.; Dai, W.; Wang, C.; Wu, G.; Guan, N.; Hunger, M.; Li, L. On the Deactivation Mechanism of Zeolite Catalyst in Ethanol to Butadiene Conversion. J. Catal. 2018, 367, 7-15. https://doi.org/10.1016/j.jcat.2018.08.019.

(55) Bonardet, J. L.; Barrage, M. C.; Fraissard, J. Use of NMR Techniques for Studying Deactivation of Zeolites by Coking. J. Mol. Catal. A. Chem. 1995, 96 (2), 123-143. https://doi.org/10.1016/1381-1169(94)00030-1.

(56) Soloviev, S. O.; Kapran, A. Y.; Kurylets, Y. P. Oxidation of Diesel Soot on Binary Oxide $\mathrm{CuCr}(\mathrm{Co})$-Based Monoliths. J. Environ. Sci. (China) 2015, 28, 171-177. https://doi.org/10.1016/j.jes.2014.08.017.

(57) Zhang, M.; Qin, Y.; Tan, X.; Wang, L.; Yu, Y.; Jiang, H. Study of Ethanol/Acetaldehyde to 1,3-Butadiene Over MgO-SiO2 Catalyst: Comparative Investigation of Deactivation Behaviour Due to Carbon Deposition. Catal. Letters 2020, 150, 1462-1470. https://doi.org/10.1007/s10562-019-03049-2. 
Graphical Abstract

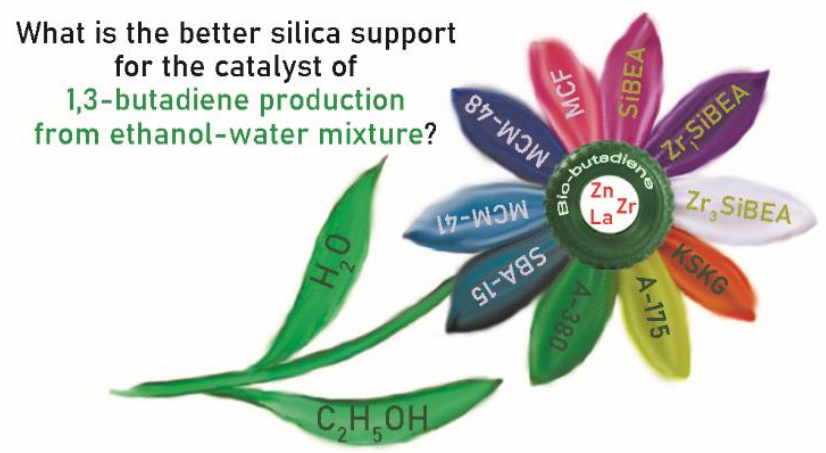

